\title{
One Belt, One Road and China's Evolution in Foreign Policy and Regional Leadership
}

\author{
Lily Ouyang \\ Global Commerce Scholar Thesis \\ University of Virginia \\ Professor Maillet \& Professor Wilhelm
}

April 28, 2017

\section{Honor Pledge}

On my honor as student, I have written the thesis independently.

Lily Ouyang

Lily Ouyang

\begin{abstract}
During his visit to Kazakhstan in 2013, Chinese President Xi Jinping unveiled the country's "One Belt, One Road" (OBOR) initiative that aims to construct a well-connected infrastructure system and integrated economy across Eurasia. Since OBOR's inception, speculations on its motivations have been rife, one of which is that OBOR is China's Marshall Plan. Although such claim has been brought up repeatedly, no research has examined its validity. This research explores whether the two strategies are comparable in nature by investigating in the economic and political motives behind OBOR and the Marshall Plan. It also examines OBOR in the context of the evolution of China's foreign policy. The conclusion is that OBOR and the Marshall Plan are comparable in an economic sense as they both helped alleviate excess capacity in China and the U.S. However, the political rationales behind the two strategies are completely different: while the Marshall Plan attempted to impose a political-economic structure, i.e., liberal capitalism, on Europe, OBOR insists in non-interventionism to minimize ideological conflict and maximize its interest. For such reason, this research concludes that OBOR and Marshall Plan have distinct natures and should not be compared.
\end{abstract}




\section{Acknowledgements}

I would first like to express my sincere gratitude to my thesis advisors William G. Shenkir Eminent Scholar Professor William Wilhelm and Associate Dean for Global Affairs Peter Maillet of the McIntire School of Commerce at the University of Virginia. They were extremely devoted to mentoring me in discovering my research interest, searching for relevant literatures, and conducting meaningful analyses on my research subject matter. They were serious in giving me intellectual challenges and generous in offering me appraisals for my efforts and progress in the research. Without their criticism and encouragement, it would be impossible for me to complete this project.

I would also like to thank Assistant Dean for Global Affairs Chris L.W. Elliot for coordinating the seminars and other research resources for the Global Commerce Scholar (GCS) program. It is his dedication to McIntire's students and academic research that makes the program possible.

In addition, I would like to thank White Burkett Miller Professor of History Philip Zelikow of the College of Arts and Sciences at the University of Virginia, who offered me important insights in the Marshall Plan. Without his input, it would be much harder for me to understand this historic event and its legacy in American history.

During the hardest time of my research, my parents and their friend, Uncle Yang, offered me encouragement constantly. I want to thank them for always supporting my passion and believing in my competence. I am excited that they can finally see the end product of my year-long effort.

Finally, many thanks to my wonderful GCS colleagues who offered me encouragement and gave me a sense of community as an independent researcher.

This research is a tremendous accomplishment at the end of my four years in college. I could not have made it without all of the people mentioned above. Thank you!

Lily Ouyang 


\section{Table of Contents}

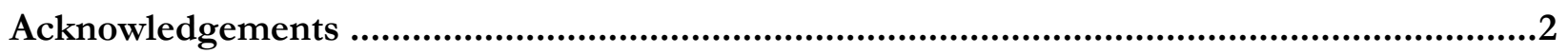

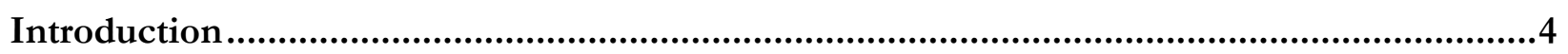

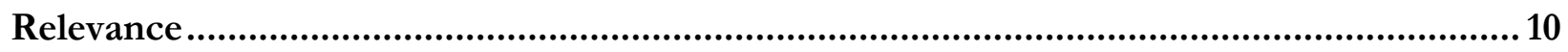

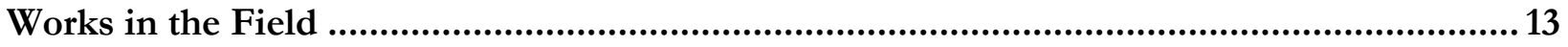

Works on OBOR

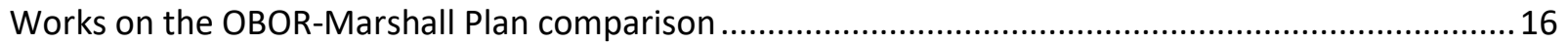

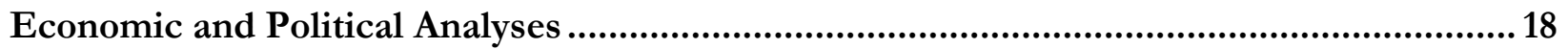

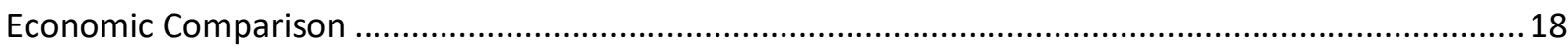

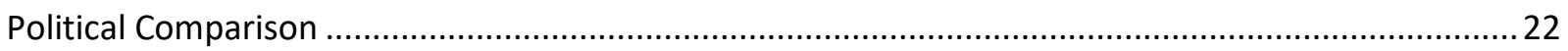

China's Foreign Policy as a Continuum........................................................................ 31

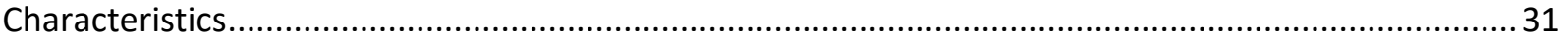

OBOR as an Extension of China's Foreign Policy and international role ..............................................37

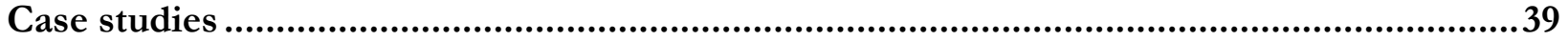

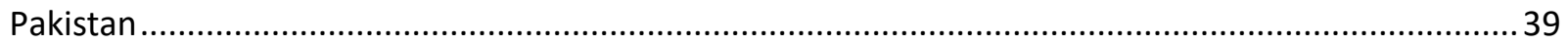

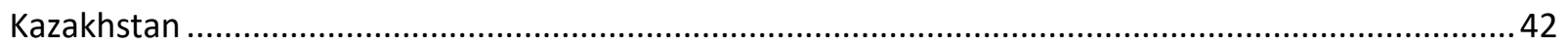

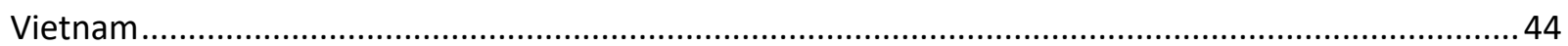

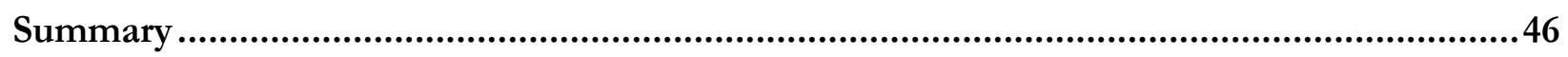

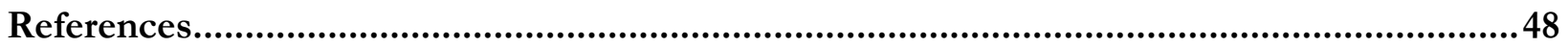




\section{Introduction}

One Belt, One Road (OBOR) is a development strategy and framework proposed by Chinese President Xi Jinping in 2013 that aims to upgrade infrastructure in 65 countries across Eurasia $^{1}$, enhance their physical interconnectivity, and subsequently strengthen the region's economic integration and political cooperation. The scope of OBOR is astonishingly broad, with a combined population of over 4 billion and a total GDP of $\$ 21$ trillion, which is about $30 \%$ of the world's GDP (Swaine, 2015, p. 3). Investment need in the first ten years is estimated to total \$8trillion (Chen \& Qian, p. 96) and the annual infrastructure investment across Asia alone will amount to $\$ 730$ billion (p. 110).

The initiative, named in honor of the ancient Silk Road ${ }^{2}$, has two components: the Silk Road Economic Belt ("One Belt") and the 21st Century Maritime Silk Road ("One Road"). The Silk Road Economic Belt is a land-based economic route that starts from Xi'an, China, meanders through Central Asia, the Middle East, Russia and Europe, and ends at Venice, Italy, linking China with the Persian Gulf and the Mediterranean Sea through Central Asia and West Asia. The 21st Century Maritime Silk Road, also referred to as the New Maritime Silk Road, is the other economic route on the sea. It starts from China's east coast, goes through the South China Sea, the Indian Ocean, the Red Sea and the Mediterranean Sea, and meets with the Silk Road Economic Belt at Venice. These two routes are subdivided into the following six economic corridors (Exhibit 1):

1. The New Eurasian Land Bridge

2. China-Mongolia-Russia Economic Corridor

3. China-Central Asia-Western Asia Economic Corridor

4. Indo-China Peninsula Economic Corridor

5. China-Pakistan Economic Corridor

6. Bangladesh-China-India-Myanmar Economic Corridor

\footnotetext{
${ }^{1}$ While OBOR primarily focuses on Eurasia, two African countries, Kenya and Zambia, are also included as for now and China plans to include more African countries in the future.

2 The ancient Silk Road was a network of trade routes more than 4,600-mile in length that stretched from Xi'an, China all the way to the Mediterranean Sea. It was central to commercial activities and cultural interaction through regions of the Asian continent for centuries during imperial China.
} 
Exhibit 1: OBOR is comprised of six economic corridors

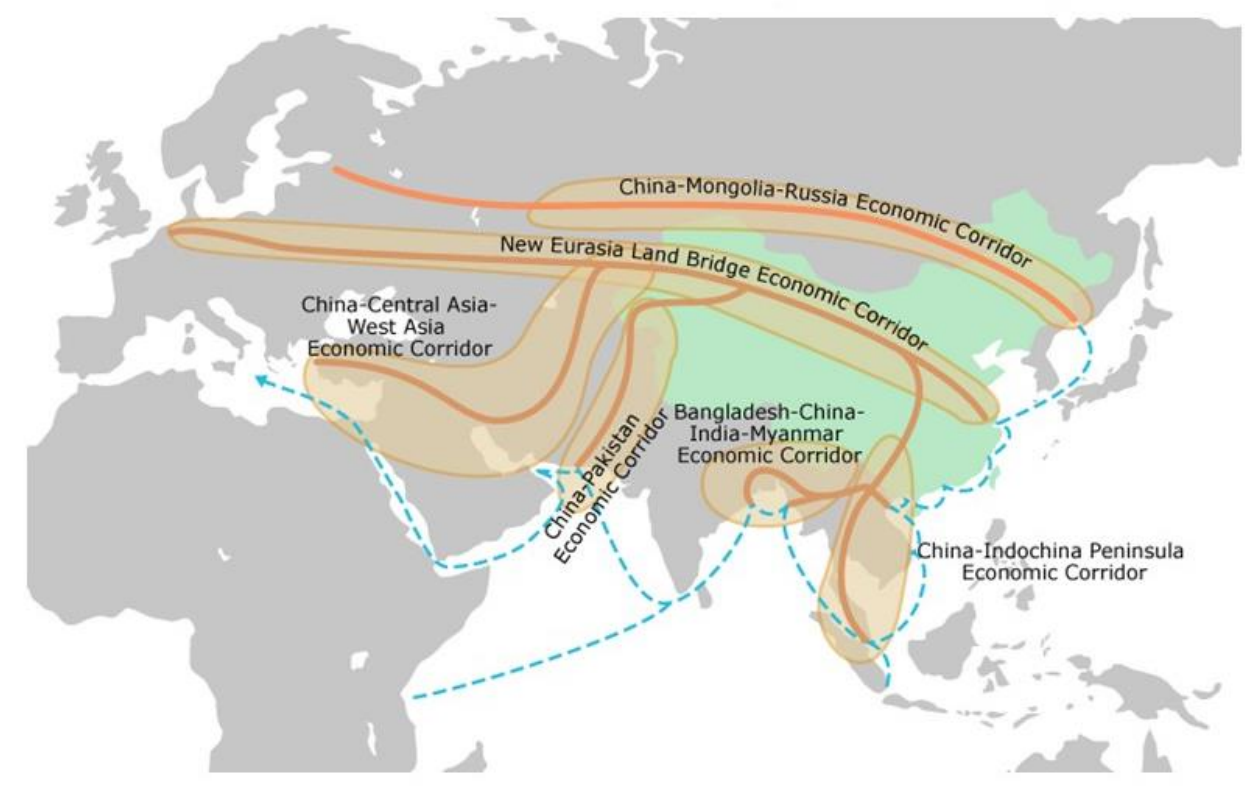

Source: Hong Kong Trade Development Council

Since its debut in 2013, OBOR has become China's "major foreign and economic policy hallmark" (Swaine, 2015, p. 16) under President Xi Jinping. The State Council, the nation's chief administrative body, has tasked China' National Development and Reform Commission (NDRC) ${ }^{3}$, Ministry of Foreign Affairs, and Ministry of Commerce to deliver the initiative's objectives (The Economist Intelligence Unit, 2016, p. 4). The major sources of financing for OBOR projects include China Investment Corporation, the Export-Import Bank of China, the China Development Bank, the Asian Infrastructure Investment Bank, and the Silk Road Fund. A large sums of foreign exchange reserves will also be directed to the projects along with limited foreign aid (Leer \& Yau, 2016, p. 4) and investments from local Chinese governments (Frolovskiy, 2016, par. 3). Although right now the investment capital mainly comes from the Chinese government and national and international financial institutions backed by it, OBOR does encourage capital inputs from the private sector.

Since OBOR was launched, China has spent much effort highlighting the collaborative, peaceful, inclusive, and positive-sum nature of OBOR, stressing that it adheres to the Five Principles

\footnotetext{
${ }^{3}$ The National Development and Reform Commission (NDRC) is a macroeconomic administrative and planning agency under the Chinese State Council. As the ministry has broad control over every aspect of China's economy, it is dubbed China's "mini State Council" and "number one ministry" (Martin, 2014, par. 4).
} 
of Peaceful Coexistence ${ }^{4}$, aligns with the purposes and principles of the UN Charter (NDRC, 2015, par. 8), and aims to construct an inclusive and non-ideological "community of interest" (Swaine, 2015, p. 10) in Eurasia. OBOR insists that it welcomes every country to join, even those not in the OBOR region. International reception to OBOR so far has been largely positive. Countries with huge infrastructure needs and without prominent conflict of interest with China, such as Kazakhstan and Pakistan, have shown enthusiasm to participate while quickly locking up deals. Some countries with precarious relationships with China, for example, Vietnam and Philippines, also expressed willingness to participate while temporarily setting aside their heated territorial disputes with their big neighbor. However, India, wary of China's motivations behind the initiative, does not show as much enthusiasm as its Asian peers. Nonetheless, although facing skepticism, OBOR has not been disturbed by explicit opposition and China has a generally favorable political climate to bring its vision to live.

Since the debut of OBOR, speculations have been rife regarding the economic and political motives behind the grand project. While some simply regard OBOR as China's attempt to dump excess productive capacity into Eurasian countries which happen to need massive infrastructure upgrade, others suspect that, with its attention currently fixed on Central Asia (for example, the fast progress in the construction of the 3000-km China-Pakistan Economic Corridor, or CPEC), the project reveals China's attempts to seize strategically important resources such as oil and gas. Among all critiques, an interesting one is that OBOR is China's Marshall Plan 5 .

Officially called the European Recovery Program, the Marshall Plan (1948-1951) was an American foreign aid program that extended $\$ 12$-billion financial aid (about $\$ 120$ billion in today's value) to 16 Western European countries ${ }^{6}$ following the WWII to prevent the spread of communism. Before the launch of this program, poverty and disillusion of both capitalism and

\footnotetext{
4 The Five Principles of Coexistence were conceived by India's first prime minister, Jawaharlal Nehru, and China's first premier, Zhou Enlai, in 1954 (United Nation, 1958). Serving as the bedrock of the relationship between China and India, the principles became widely known at the Bandung Conference in 1955. The articles of the Principles are:

- Mutual respect for each other's territorial integrity and sovereignty

- Mutual non-aggression

- Mutual non-interference in each other's internal affairs

- Equality and cooperation for mutual benefit

- $\quad$ Peaceful co-existence (Swaine, 2015. p. 4)

5 The profile of the Marshall Plan can be found in "Appendix 2: Profile of the Marshall Plan".

${ }^{6}$ Austria, Belgium and Luxembourg, Denmark, France, West Germany, Greece, Iceland, Ireland, Italy and Trieste, Netherlands, Norway, Portugal, Sweden, Switzerland, Switzerland, United Kingdom.
} 
fascism had swung Europe leftward. The clear ideological line between capitalism and communism was blurred (Reynolds, 1997, p. 171). In Eastern Europe lands were redistributed and industries were brought under government control. The climates in the west were not that different: voices from socialist democrats and communists resounded in Britain, France, Italy, and Belgium (p. 171). Washington feared that as Europe slid further into economic distress, it would inevitably turn itself into communism and fall under the Soviet Union's sphere of influence. If this happened, two disastrous consequences would ensue. First, the world's most powerful economy would lose an entire continent of trading partners. More importantly, the Americans feared that communism would spread like a contagious disease to other parts of the world. The resulting hostile ideological climate would force the steward of liberal capitalism to be militarized and revert to wartime central planning. Liberal capitalism, the core value of the U.S., would thus be undermined (Hogan, 1987).

Such logic convinced the U.S. to extend aid to European countries on the premise that they stop anti-liberal-capitalist practices such as central planning and highly tariffs on cross-border trade. More importantly, the U.S. demanded that Europe proposed a recovery plan collectively. This demand had several objectives. First, it promoted trans-national coordination of resource allocation to ensure most efficient distribution of aid resources. Second, trans-national collaboration would facilitate Europe's economic integration. This was essential because an integrated European market meant that if one country wanted to revert back to central planning, the "invisible hand" in the bigger market would render its effort in vain. The core of this mechanism was to effectively aid Europe's economic recovery while simultaneously alter its politico-economic system which was threatening to America's universal value in the long-run (Hogan, 1987).

While a free market capitalist system in Europe ensured a congenial international economic environment for the U.S. in the long-run, the Marshall Plan also bore short-term economic benefits. During the ten months when the plan was being formulated, American export dropped by almost one third (Carew, 1987, p. 9-10). The U.S.'s productive capacity in excess would require rapid restructuring of the American economy, which, if not impossible, would be detrimental to the country's wellbeing. However, if the U.S. extended aid to Europe, the money would largely flow back to the U.S. for purchases of essential commodities that Europe was incapable to produce, absorbing the U.S. excess capacity. Such short-term economic benefit was also an important consideration. 
The rationale behind the OBOR-Marshall Plan comparison lies in that they both served similar objectives. Economically, they helped to alleviate domestic excess productive capacity. On the political side, they were designed to counter powerful political rivals and establish new international orders according to China's the U.S.'s ideologies. However, although such arguments were frequently made, no research has dug deep enough to determine whether the two are qualitatively and quantitatively comparable. In the hopes of providing insights in the nature and motives of OBOR, this research will compare it with the Marshall Plan in terms of both plans' intentions and political motivations. It will also put OBOR in the context of China's evolving foreign policy in order to illustrate that OBOR is an organic extension of China's foreign policy.

The analyses of this research show that OBOR and the Marshall Plan are quite similar from an economic point of view. Both strategies aimed to export domestic excess capacity. The U.S. extended aid to Europe after seeing an annual excess capacity worth $\$ 14$ billion as a result of sharpe decline in export (Carew, 1987, p. 9). OBOR serves a similar purpose by shifting out tons of products from traditional industries (steels, glass, cement, etc.) to where OBOR projects take place overseas. Therefore, this research argues that OBOR and the Marshall Plan have comparable economic motivations.

When it comes to political motives, things get a little tricky. OBOR and the Marshall Plan's political impacts seem similar. While the Marshall Plan prevented more wars in Europe, OBOR is poised to enhance Eurasia's security through improved economic conditions and better regional policy coordination. While the Marshall Plan aspired to counterbalance the Soviet Union's communist influence over Europe, OBOR hopes to siphon away diplomatic support from Eurasian countries to fend off the U.S.'s “Asia Pivot." At the end of the day, the Marshall Plan helped the U.S. to remake the international political order according to its vision, i.e., liberal capitalism. On the other hand, OBOR helps China to export an "alternative" international economic and political order that is consistent with its value, i.e., non-interventionism. Although the Marshall Plan did intend to seize natural resources overseas, in contrast to what OBOR is doing, it seems that the OBORMarshall Plan comparison makes sense.

However, this research argues that although the two strategies have similar political results, the ideological rationales behind them are fundamentally different. At its core, the Marshall Plan was designed to prevent the spread of communism. In other words, it was an ideological move with an American political undertone that liberal capitalism is universally true and should be adopted by 
every country. OBOR, on the other hand, advocates ideological-neutrality and non-interventionism (although the research will point out later that adherence to these principles will become increasingly challenging). By design, OBOR is not to promote the Chinese ideology, but to maximize China's interest (access to natural resources, control of trade routes, influence over regional security, etc.) in the current international economic and political systems. Such interest is always a reflection of China's pressing domestic concerns.

This research will illustrate that OBOR is an organic extension of China's foreign policy since the 1950s. Many of the principles underlying OBOR that sound like pure rhetoric in fact reflect China's fairly consistent approach to international engagement. The "going out" of domestic enterprises that OBOR advocates is not a decision that Beijing made suddenly but has its roots in the late 1990s. The ideological neutrality and non-interventionism are not just sweeteners that Beijing added to OBOR in order to lure more participants. Instead, they have been important pillars of China's foreign policy for more six decades and reflect China's political realism and pragmatism as a result of the country's perpetual need to prioritize pressing domestic issues over international concerns.

Nevertheless, OBOR also shows that China's interpretation of these principles are evolving. It is important to keep in mind that China had been investing heavily overseas and taking on more regional and global leadership before the launch of OBOR. Its (re)branding of activities that had existed long before OBOR reveals a shift of its self-identification: instead of "keeping a low profile" and "hiding its capability" (“tao guang yang hul") under the leadership of Deng Xiaoping, OBOR articulates China's ambition to "strive for achievement" ("fa fen tu qiang"), a vision embedded in President Xi Jinping's leadership. China's verbalization of OBOR's alignment with the UN Charter shows that the Asian giant does not yet have the will to revolutionize the current international order. Nevertheless, as OBOR is branded as an “alternative” means of international cooperation, China's longing to become one of the global powers is obvious. 


\section{Relevance}

There are as many literatures claiming that OBOR is China's Marshall Plan as those arguing that it is not. While influential news agencies including Bloomberg, The New York Times, The Wall Street Journal, and The Diplomat all issued diverse opinions on this matter, no research has been done in an academically rigorous manner.

But why do people want to know the validity of the comparison in the first place? Why is China so sensitive to the Marshall Plan, constantly labeling it as "western imperialism" with a "Cold War Mentality" while, on the other hand, the rest of the world remains either skeptical towards China's zealously advertised non-interventionism or appreciative of the legacy of the Marshall Plan?

The significance of this research is embedded in the Comparison itself. Today, while some western historians have become aware that it may not be meaningful to judge China from a purely western lens, others still do so, and the comparison is their attempt to fit China's political rationale into frameworks that they can understand. They find the Marshall Plan is one such framework. On the other hand, China's condemnation of the OBOR-Marshall Plan comparison can be understood as its continued effort to boycott the U.S.'s interpretations of Chinese values - which the world does recognize as idiosyncratic - based on American ideologies. Therefore, the significance of the research is that, instead of adjudicating who is right and who is wrong in the OBOR-Marshall Plan comparison battlefront, it seeks to answer whether such Comparison is sufficient to understand OBOR, China, and even the Marshall Plan and the U.S.

It is important to note that OBOR is an organic part of China's economy and politics as much as the Marshall Plan was an integral component of the U.S.'s ideology and foreign policy. Unfortunately, current research approaches OBOR without putting it in the context of China's evolving foreign policy. To be more specific, the research is constructed as if OBOR was brought to the table suddenly, either as a contingent plan which policymakers in Beijing scrambled to put forward in response to a domestic economic predicaments, or as a strategic countermove to balance the U.S.'s "Asia Pivot"”. They fail to take into account that China's many foreign policies with a hint of the OBOR spirit (non-interventionism, the "going out" strategy, mutual benefit, etc.) existed

\footnotetext{
7 The quick rise of Asian economies convinced the Obama administration that the U.S. needed to stay involved in the Far East economically, militarily, and diplomatically (Collinson, 2016, par. 3). He stated that "America has to write the rules of the 21 st century economy in a way that benefits American workers. If we don't, countries like China will write those rules in a way that benefits their workers" (par. 17).
} 
decades ago. Therefore, a rigorous understanding of OBOR inevitably requires the apprehension of China's foreign policy from 1979 to present.

The ideologies, political economies, and foreign policies of China and the U.S. often stand in exact opposition to each other, just as they are on the earth geographically. While it is audacious to claim that China and the U.S. don't understand each other, it is reasonable to say that the majority of people from both countries fail to comprehend why the opposing party behaves in certain ways that depart from their values. Whether China's officials genuinely reject the merit of the Marshall Plan or not (in every public situation they drop the OBOR-Marshall Plan comparison like a hot potato), there is no doubt that the majority of the Chinese do because the leadership has taught them so. On the other hand, many American analysts have assumed an equally frivolous attitude towards OBOR. As ridiculed and lamented by Chance from The Diplomat, "one think tank expert inferred an ominous geopolitical intent behind the $\mathrm{AIIB}^{8}$, without even bothering to get the name of the institution right" (Chance, 2016, par. 12). Therefore, the significance of this research also lies in that it strives to channel mutual understanding between China and the U.S.

By economic size, China and the U.S. are the two largest countries in the world, and their interdependence has grown increasingly strong. In 2015, GDPs of the U.S. and China reached \$18 trillion ${ }^{9}$ and $\$ 11$ trillion respectively ${ }^{10}$, with trade between them amounting to $\$ 598 \mathrm{bn}^{11}$, making up $3 \%$ of U.S.'s GDP and $5 \%$ of that of China. Neither of the two can afford to lose the cooperation and partnership from the other. As China’s former president Jiang Zemin once put, "if a leader deals with it [Sino-U.S. relations] well, they will be great leaders" (Lampton, 2014, p. 124). Sino-U.S. relations not only affects the two countries' international interests, but also shapes the legitimacy of the leaderships at home. By giving a deep, thoughtful, holistic, and relatively unbiased analysis of

\footnotetext{
8 The Asian Infrastructure Investment Bank (AIIB) is an international and multilateral financial institution initiated by China and founded by more than 50 members. With current capital of $\$ 100 \mathrm{bn}$ and its investment capacity projected to reach $\$ 250$ billion by the end of 2020 (Gallagher et al.), the Bank aims to provide financing for infrastructure development in the Asia-Pacific region. It is regarded as an institution that China established to serve OBOR.

9 "GDP (current US\$) \& United States." World Bank National Accounts Data, and OECD National Accounts Data Files. 2016. Web. Data assessed on 22 Jan. 2017. <http://data.worldbank.org/indicator/NY.GDP.MKTP.CD?locations=US>.

10 “GDP (current US\$) \& China." World Bank National Accounts Data, and OECD National Accounts Data Files. 2016. Web. Data assessed on 22 Jan. 2017. <http://data.worldbank.org/indicator/NY.GDP.MKTP.CD?locations=CN>.

${ }^{11}$ Office of the United States Trade Representative. "The People's Republic of China." Office of the United States Trade Representative. Executive Office of the President. Web. Assessed on 22 Jan. 2017. < https://ustr.gov/countriesregions/china-mongolia-taiwan/peoples-republic-china $>$.
} 
OBOR and the OBOR-Marshall Plan comparison, the last significant point of this research, and the humble wish of the researcher, is that it would contribute to the two nations' mutual understanding of each other so they will better cooperate with each other in the future. 


\section{Works in the Field}

\section{Works on OBOR}

Since the inception of OBOR, both Chinese and international news agencies, consultancies and academia have published news coverages, commentaries, reports, and research on the topic. Many of them are mere descriptions of known facts or representations of opinions and commentaries published elsewhere. While this research does use these works as references, they will not be detailed here. The works presented below, however, go beneath the surface and provide insights into OBOR.

Chinese Views and Commentary on the "One Belt, One Road" Initiative (Swaine, 2015)

Published on the Hoover Digest, a quarterly publication by the Hoover Institution, this research paper not only gives a quick fact check of OBOR's vision, scope, principles, and design but also integrates interpretations of OBOR's motives from various angles including economic benefits, political implication, and strategic considerations. Since these interpretations are drawn from authoritative, quasi-authoritative, and non-authoritative Chinese sources ${ }^{12}$, they provide a multilayered narrative of OBOR from a Chinese lens.

\section{Articles on OBOR by The Diplomat}

A Tokyo-based online international news magazine covering politics, society, and culture in the Asia-Pacific region, The Diplomat approaches OBOR in a relatively balanced manner. As different writers contribute to the collection of articles on OBOR, the magazine does not have a uniform voice on the Chinese initiative. However, these coverages do demonstrate some common patterns. Most of them approach OBOR by examining the interaction between China and diverse OBOR constituents. They also put OBOR in the context of China's evolving domestic and international priorities, tracing Chinese policies back to their historical roots. In general, these articles suggest that OBOR is a manifestation of China's re-self-identification internationally, and that the effectiveness

\footnotetext{
12 While Commentary never directly defined "authoritative sources", "quasi-authoritative sources", and "nonauthoritative sources", by context, it is reasonable to interpret the first as documents from branches within China's central government (Swaine classified Ministry of Foreign Affairs and the Ministry of Commerce as "authoritative"), the second as institutions or people within institutions affiliated with the central government (Swaine classified Wu Jianmin a former president of China's Foreign Affairs University, which is attached to the Ministry of Foreign - as a quasiauthoritative source) and the third as any other source not in the previous two categories.
} 
of the grand project will depend on whether China can address the diverse interests of OBOR stakeholders.

\section{China Brief}

A publication of the James Foundation, China Brief has a collection of articles that provide insights to OBOR's geopolitical and military motivations, portraying China as a "gamer" in Eurasia who seeks to maximize its geopolitical interest (e.g. access to the Indian Ocean) by taking moves and countermoves against its political rivals. Focusing on China's foreign policies in general - not just OBOR - it puts OBOR in the context of China's current economic and political climates. Some articles also treat OBOR as an extension of China's historical international activities. For example, when analyzing China's engagement in Central Asia today, Downs (2015, p. 3-4) pays special attention to China's activities predating the inception of the initiative, concluding that, although China's activities in Central Asia will intensify, this should not be attributed to OBOR but rather to China's long-term needs to secure critical resources (e.g. oil) for its development. In short, China Brief offers important insights when it comes to an analysis of OBOR's geopolitical implication.

One Belt One Road: A Financial Perspective (Chen \& Qian, 2016)

This book collects articles on OBOR written by Chinese experts from the "China Finance 40 Forum", a non-governmental think tank made up of 40 economic and financial pundits. It looks at the financial priorities, challenges, and mechanisms of the initiative from the perspectives of Chinese economic and financial experts, and is instrumental to this research in understanding how Chinese top leadership and elite interpret the strategy and how they think it should be executed going forward. With seven chapters collecting 50 articles, the book covers a wide range of topics ranging from OBOR's high-level design (e.g. multilateral cooperation) to more mundane matters such as logistics (e.g. upgrading China's financial service capabilities). Although this research does not focus on the mechanisms of OBOR, it is important to have a high-level understanding of them, as they are reflections of OBOR's top priorities, from which we can infer the motives behind the initiative. Collectively, these articles convey that China should align OBOR with its participants' national agendas and deliver the "mutual benefits" the initiative has promised. The experts in the book also emphasize that OBOR should be implemented in a way that is consistent and complementary with the goals and priorities of existing multilateral cooperation mechanisms, for example, Association of Southeast Asian Nations (ASEAN) and Shanghai Cooperation 
Organization (SCO). In addition, they state that OBOR is a progressive step China has taken under the "going out" strategy devised by the former President Deng Xiaoping three-and-a-half decades ago. Nevertheless, as China's economic strength grows, the "what" and "how" of the "going out" should be re-identified.

Although the literatures aforementioned provide insights in OBOR, they fail to paint a big picture of it. All of them focus heavily on certain considerations of OBOR without diving as deep into the others. For example, Chinese Views and Commentary on the "One Belt, One Road" Initiative pays special attention to the Chinese narrative. In other words, it presents how OBOR is framed and marketed by the Chinese. It pays less attention to non-Chinese perspectives, thus making the OBOR story lopsided to the Chinese side. More importantly, while this paper succeeds in integrating Chinese views on OBOR and showing their nuances on top of their shared principles, it falls short in analysis.

The Diplomat, in contrast to Commentary, weighs analysis heavily. However, its analysis often comes from a geopolitical perspective and much less from an economic one. As this research will conduct statistical analysis on the impact that OBOR and the Marshall Plan have on China's and the U.S.'s trade and exports, the insights the magazine presents are insufficient. The same limitation is found in China Brief, which mainly offers geopolitical and military narratives of OBOR.

The Belt and Road: A Financial Perspective is a work from Chinese "insiders" affiliated with the government. For such reason, it inevitably carries biases and downplays non-Chinese critiques. What's more, as suggested by its name, this work examines OBOR from a financial angle. The geopolitical side of the coin is unaddressed.

Last but not least, none of the current literatures put OBOR in the context of China's foreign policy evolution since 1979. It is important to keep in mind that China has been investing in major OBOR countries and engaging in policy cooperation with them since the turn of the millennium. From an economic perspective, OBOR could be - in full or partially - an extension of China's existing investment momentum in Eurasia. On the political side, OBOR is likely to stay consistent in principle with China's foreign policy since 1979. While The Diplomat and China Brief do trace OBOR's principles back to China's foreign policy occasionally, they do not show its evolution.

Given the merits and limitations of the literatures aforementioned, this research tries to conduct a thorough analysis of the economic, political, and strategic deliberations behind OBOR, validating and rejecting the various claims and hypotheses in existing literatures. Such analysis, more 
importantly, will not be conducted as if OBOR was born all of a sudden, but instead, treats OBOR as an organic component and product of China's domestic and international concerns, development, and leadership.

\section{Works on the OBOR-Marshall Plan comparison}

Among the diverse interpretations of OBOR, the OBOR-Marshall Plan comparison appears frequently, both from Chinese and non-Chinese sources. Non-Chinese sources are often in support of the Comparison, arguing that both of them serve to boost export and counter political rivals. Official Chinese sources contrast OBOR against the Marshall Plan. They stress that the former is open and free of ideological considerations while the latter is a manifestation of the U.S.'s "Cold War Mentality", ideological exclusivism, and the construction of a sphere of influence. While such comparisons are often made, no research has been done to test its validity in an academically rigorous manner. Therefore, this research will do the work from economic and political perspectives. Analysis on OBOR will be based on literatures on OBOR since 2013 from the mainstream newspapers, academia, consultancies, and the Chinese central government. Understanding of the Marshall Plan will mainly be based on Hogan and Reynolds, who are academically recognized historians of the Marshall Plan and WWII, respectively.

It is imperative not to take either OBOR or the Marshall Plan at their "face value", which oversimplifies and even distorts the true motives behind the strategies. As Chance from The Diplomat puts it:

However, it is important to remember on all sides that no foreign policy is monolithic. No strategist speaks for a whole nation, nor do all interests within a country operate according to a concerted plan. In fact, competing nations tend to overstate the centralization and coordination of one another's plans and they tend to view the actions of their counterparts in a negative light. Both of these patterns can be observed in Chinese criticism of U.S. policy and American fears of Belt and Road (Chance, 2016, par. 10).

Indeed, grand and influential as they both were and will be, it is naïve to simply characterize OBOR and the Marshall Plan's motivations as "altruistic" and their impact as "successful". It is equally narrow-minded to dismiss them as ill-intended or ineffective. After all, with the $\$ 8$ trillion planned investment into the OBOR region, the initiative will bring OBOR countries at least material benefits, regardless of what China's true motivations are. On the other hand, the Marshall Plan did succeed in preventing Europe from more wars and mutual aggression after WWII, accelerating their 
recovery, and ensuring democracy. In fact, we should be very cautious to say whether OBOR "is" or "is not" another Marshall Plan. As they are both two big countries' expansion outwards, they will certainly share some similarities. However, when we examine the ideologies, political economies, and historical experiences of the two countries, we find that they largely stand exactly opposite to each other. Therefore, this research will be oriented to treating OBOR and the Marshall Plan as China's and the U.S.'s searching for world orders in their own visions. The structure of this research and its methodology will be detailed in the next section. 


\section{Economic and Political Analyses}

As discussed in the previous section, current literatures on OBOR are fragmented and incomplete. Without a framework upon which OBOR can be systematically examined, it is hard to understand OBOR. This - along with the much argued but never testified OBOR-Marshall Plan comparison - inspires this research to seek understanding of OBOR by borrowing the framework of the Marshall Plan. This research will first compare OBOR with the Marshall Plan ("horizontal comparison") and then examines OBOR's linkage to China's foreign policy since the 1950s ("vertical comparison"). The comparison will be conducted from economic and political perspectives detailed below.

\section{Economic Comparison}

In late 1940s there was strong belief that a recession was going to hit the U.S. as the war ended. Long before American leaderships started to devise strategies to contain communism, economists in the country noticed that post-war Europe's economy was deteriorating, which seriously threatened the U.S.'s exports and the country's economic development as a whole. It was forecasted that American exports to Europe would decline by more than one third in the next year without financial aid to boost trade between the two continents. That prediction came true during the ten months when Marshall Plan was being formulated. The economic disaster justified and expedited the launch of the Marshall Plan (Carew, 1987, p. 9-10).

Excess capacity is an unfavorable economic state in which productive capacity is used inefficiently. It is the difference between total productive capacity (how much could be produced when all equipment and labor are used fully) and actual productive needs (how much is actually produced in response to demand in the market). According to international standards, normal capacity utilization rate is $80 \%-89 \%$. Higher than $90 \%$ implies insufficient capacity. $75 \%-79 \%$ implies excess capacity while below 75\% signals severe excess capacity (Zou, 2016, par. 3). Had Europe's economy melted down, the U.S. would have a huge amount of productive capacity in idle, thus suffering from excessive capacity.

In recent years, China has been faced with similar problems in excessive capacity from traditional industries including steel, electrolytic aluminum, shipbuilding, etc. The problem was mainly caused by central and local government policies incentivizing over-expansion of production 
capacity in strategically important industries due to overly optimistic expectations of the country's economic expansion in the past decade. The following section will examine the severity of China's excess capacity. As this problem is found in a series of industries, this research will not describe them one by one but instead closely examine the one receiving most attention: steelmaking.

Exhibit 2 computes steelmaking's capacity in excess from 2008 to 2015 using $80 \%$ as the benchmark normal capacity utilization ${ }^{13}$. In the exhibit, excess capacity becomes visually conspicuous after 2012 and keeps increasing. In 2015, the number reached all-time high at 156 million metric tons. Exbibit 3 computed loses from wasted capacity by multiplying the capacity in excess with the steel price in each year (Focus Economics, 2017). The result is an astonishing $\$ 70 \mathrm{bn}$ of potential revenues from steel products lost. That alone makes up $3 \%{ }^{14}$ of China's total export of goods in 2015. China should be desperate to search for markets to alleviate this burden.

Exhibit 2: Steel excess capacity rapidly increased after 2012

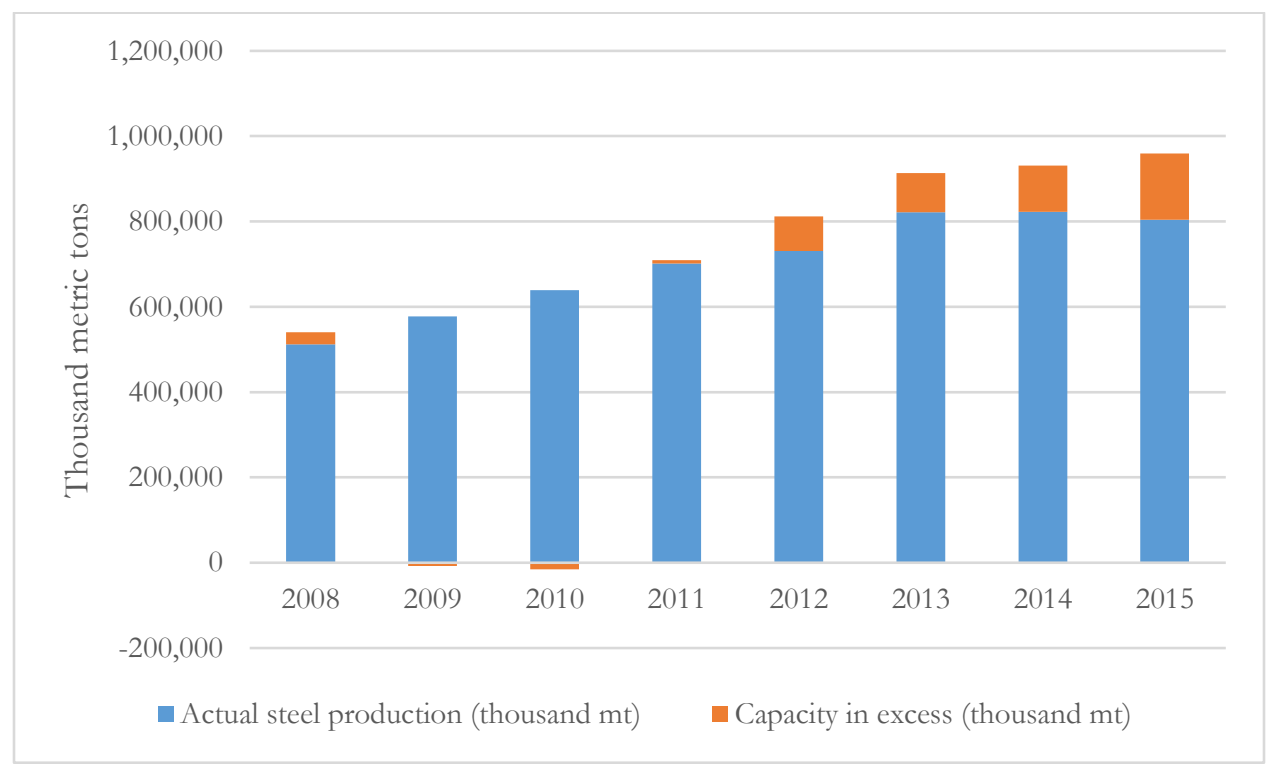

\footnotetext{
13 The excess capacity computed is computed by the researcher using data from China's State Information Center (2016, Exhibit 2) and the World Steel Association (2016, p. 2).

14 'The researcher's computation is based on the yearly excess capacity and China's total export of goods in 2015, obtained through Statista (2016).
} 
Exhibit 3: China's loss from excess capacity in steel amounted to $\$ 70 \mathrm{bn}$ in recent years

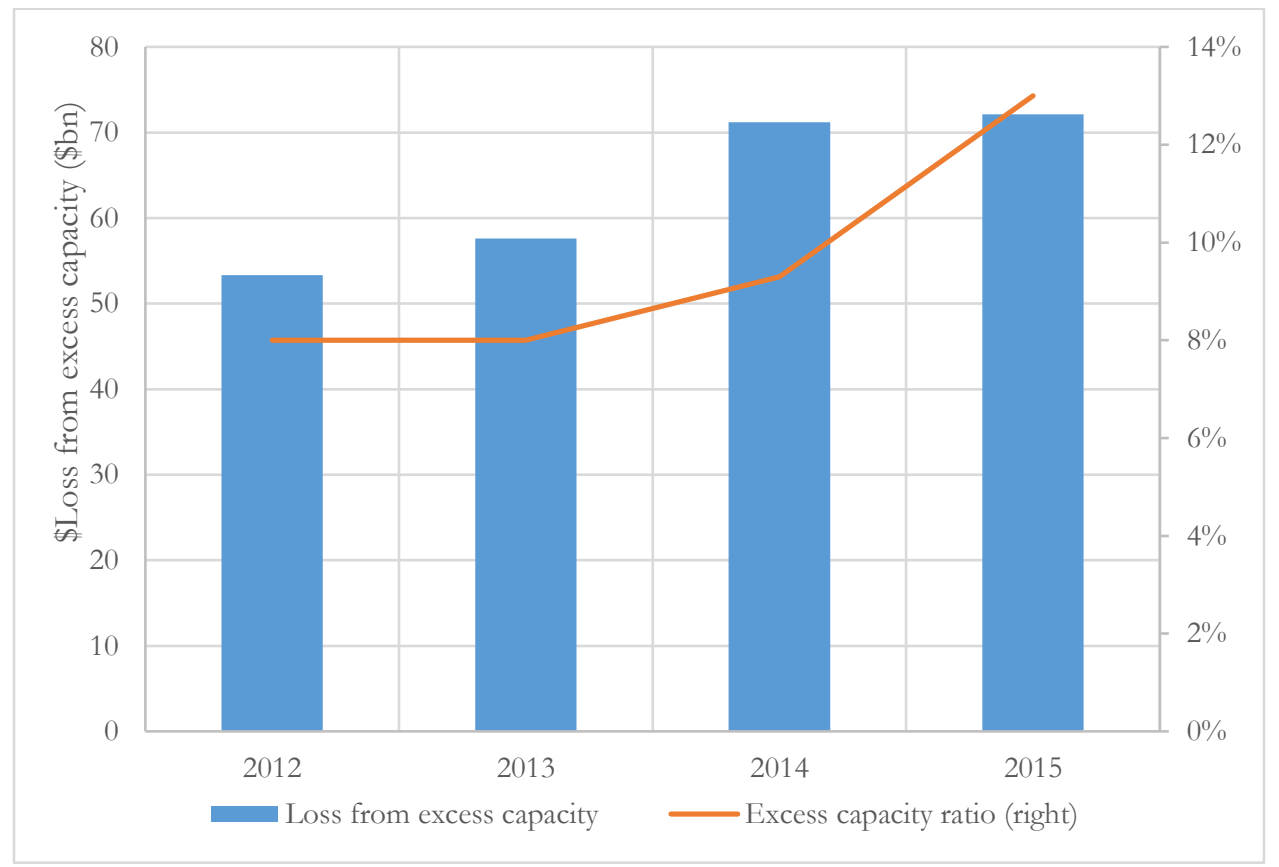

On October 6, 2013, China's State Council issued the "Guiding Opinion on Eliminating Severe Excess Capacities" (hereinafter referred to as the "Guiding Opinion"), highlighting the pressing needs to cope with excess capacity. Among the eight "major tasks" it listed, one of them is "actively expand foreign development space" (General Office of the State Council, 2013, par. 24). The timing of the "Guiding Opinion", the inclusion of oversea economic expansion as a "major task", and the launching of OBOR make it convincing that China is purposefully using OBOR as a means to cope with excess capacity. In reality, Exhibit $4^{15}$ confirms that this hypothesis is valid. China's export of semi-finished and finished steel products took a leap after OBOR was launched. This trend is seen in other steel products, too. Therefore, at least for steel alone, OBOR became a conduit for China's excess capacity export.

${ }^{15}$ Data from the World Steel Association (2016, p. 53). 
Exhibit 4: China's export of semi-finished and finished steel products skyrocketed after 2013

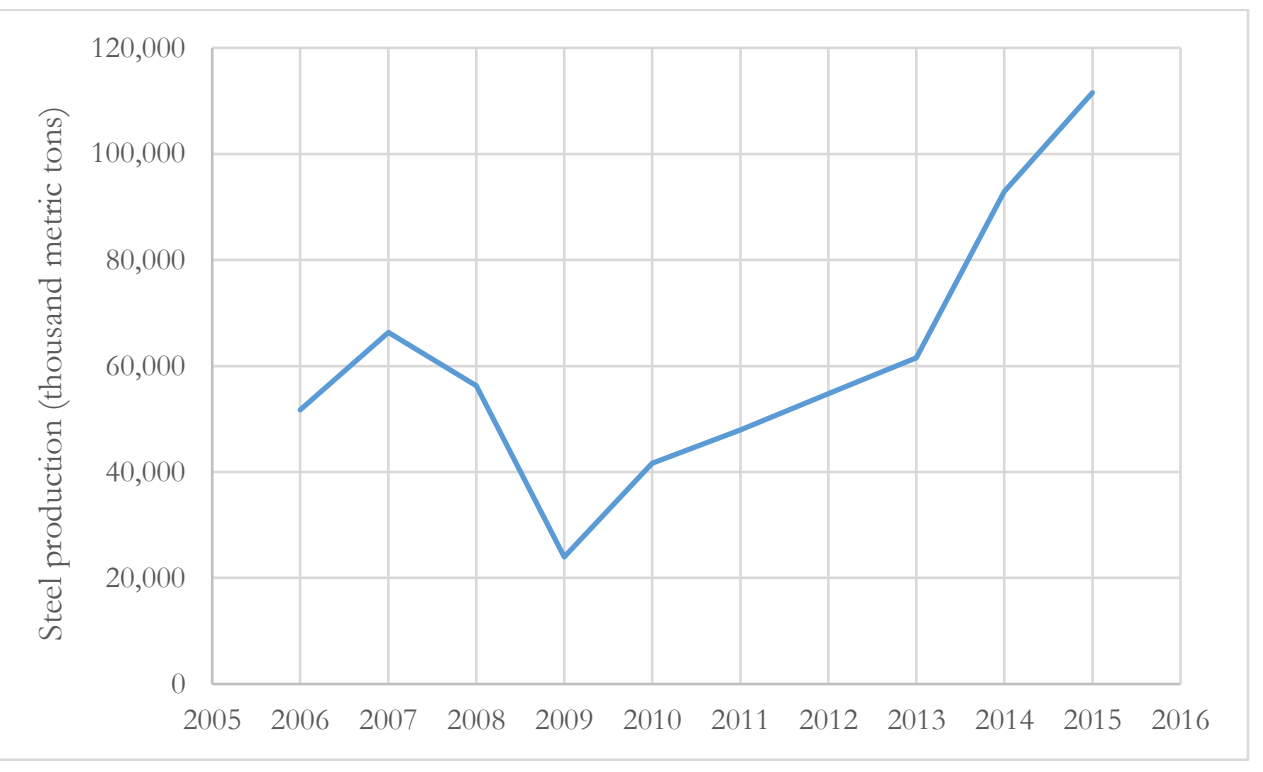

The current predicament of China's steel industry is fairly representative of the overall excess capacity problem. According to the General Office of the State Council (2013), the utilization rates of the top five industries with the most severe excess capacity were all below the $75 \%$ line (iron \& steel: $72 \%$, cement: $73.7 \%$, electrolytic aluminum: $71.9 \%$, flat glass: $73.1 \%$, and shipbuilding: 75\%), showing severe excess capacity.

An official from China's Ministry of Industry and Information Technology stated that "for us there is overcapacity, but for the countries along the 'One Road One Belt' route, or for other BRIC nations, they don't have enough and if we shift it out it will be a win-win situation" (Brun, 2016, p. 43). This has two implications. First, OBOR is indeed used to cope with the overcapacity in China. Second, OBOR is just one of the many means. In other words, OBOR is under a broad and general scheme to push overcapacity overseas. This is evident when we consider where Chinese industry cartels are going in the world. While a lot of capacity shifted out took place in OBOR countries, African countries have also been absorbing China's capacity even though they are not part of OBOR. For example, while Shougang, set up operations in Malaysia with a capacity of 3 MT in 2015 (p. 43), Hebei Iron and Steel Group plans to complete developing 5 MT of steelmaking capacity in South Africa by 2019 (p. 43).

While this strategy has been effective in some countries while failed to accomplish its mission in the others. For example, the International Trade Administration (2016, p. 5) revealed that 
“the import market share for China's steel products increased in all of China's top export destinations [South Korea, Vietnam, Philippines, Indonesia, India, Thailand, Malaysia, Singapore, Turkey, Italy] except India”. The case study on Pakistan in the end of this research will also show that the Central Asian state's steel import from China became unprecedentedly high after 2013. Nevertheless, the case study on Kazakhstan tells a different story and Chinese steel export there has been in steady decrease year by year, probably due to the growth of the country's domestic steelmaking industry.

Although the overcapacity problem is a tough one, we are not likely to believe the narrative which claims that the Chinese government devoted $\$ 4$ tn to a pan-Eurasian project just to eliminate China's excess capacity, especially when the government already realized the unsustainability of the old growth model of traditional industries. Besides, the current demand for steel in Asia is not sufficient to absorb all of China's excess capacity. “China would need $\$ 60$ billion per year of extra demand to absorb excess capacity...The economies of Central Asia are not that large" (Brun, 2016, p. 43). This paper argues that OBOR, while it reduce excess capacity, is not fundamentally designed to do so.

To conclude, from an economic point of view, the Marshall Plan and OBOR have a high degree of resemblance. One of the key considerations behind the Marshall Plan was that without extending aid to help recover Europe's economy, the U.S.'s export would drop by one third and an annual excess capacity worth $\$ 14$ billion would drag the U.S. into a recession. On the other hand, China has been burdened by excess capacity in traditional industries. The capacity utilization rates in steel \& iron, electrolytic aluminum, cement, flat glass, and shipbuilding are below $75 \%$, indicating that the excess capacity is severe. The annual loss as a result is tremendous. That in steelmaking alone amounts to $\$ 70$ billion, making up 3\% of China's total exports of goods. In addition to economic loss, increasing capacity that sits in idle also causes displacement of workers and impacts social stability. Faced with these obstacles, China resorted to expanding markets overseas, similar to what the Marshall Plan did in order to cope with domestic economic plights.

\section{Political Comparison}

The Marshall Plan had a "chain" of political objectives, with each of them paving the way for the next. The first one was to provide immediate poverty relief to mitigate European countries' mutual aggression and prevent the possibility of more wars. The European economy could then 
recover in peace. The strict anti-communist practices that the U.S. imposed allowed free market capitalism to take root. This secured the U.S. a congenial politico-economic environment in Europe for trade and investment in the long-run. The final result was the U.S.'s victory in countering the Soviet Union and strengthening its status as the world's super power. This chain of objectives can be summarized as follows.

1. Prevent wars in Europe

2. Counter communism and defend liberal capitalism

3. Secure a congenial political-economic environment for future trade and investment

4. Counter a political rival (the Soviet Union) and strengthen the U.S.'s global leadership

When it comes to OBOR, things get a little fuzzier. While the official political objective behind OBOR is to "deepen political trust" (NDRC, 2016 par. 18) between China and its peers, it is unclear what China wants from the cemented ties. The rest of this section seeks to answer this question. Corresponding to the Marshall Plan's four political objectives listed above, OBOR's motives can be categorized as follows:

1. Enhance security in Eurasia

2. Counterbalance the U.S.'s "Asia Pivot"

3. Seize strategically important natural resources and trade routes

4. Establish a "Community of Interest" under the Chinese leadership

The rest of this section will analyze each of them in detail.

\section{Enhance Political and Territorial Security}

To China, its relationships with neighbors on the southeast are strategically important. With Japan and Korea sitting on its east as American allies, China would not want to see more American influence on its southeast. If that happened, a U.S. encirclement would not be faraway. Aware of its southeastern neighbors' strategic importance, China formed a strategic partnership with the Association of Southeast Asian Nations (ASEAN) in 2003. However, the Sino-ASEAN relations recently deteriorated with Beijing's increasing assertiveness in the South China Sea. In this context, OBOR can be used as a diplomatic measure to mitigate heightened territorial disputes, and strengthen China's relationships with its neighbors in the southeast. In other word, OBOR is being used to forge key economic arrangements with Southeast Asian states that will afford China greater access to that region over the long term. In 2016, back-to-back visits by Philippine and Malaysian leaders to Beijing was a sign that China's strategy had borne fruit. Philippines promised "separation" (Clover \& Peel, 2016, par. 3) from Washington and claimed that it was "springtime" (par. 5) in 
Beijing-Manila relations. In the meantime, Malaysia made its first defense deal with China while admonishing the West not to lecture on the Southeast Asian country's embrace of China's investment in the nation (par. 6). In Indonesia, Chinese investment jumped fivefold between 2015 and 2016 (Wataru \& Maulia, 2017, par. 3). In September 2016, China and Vietnam stepped back from their aggression towards each other and agreed that maritime issues should be appropriately handled in a peaceful way on the basis of equality and mutual respect, and not allow maritime issues to affect the development of relations (Jennings, 2017, par. 1).

In 2013, China was ASEAN's largest individual trading partner, taking credit for $14 \%$ of total ASEAN trade (Salidjanova et al., 2015, p. 4). To ASEAN states, a good relationship with China means that their biggest trading partner will continue to be a major contributor to their economic prosperity. To China, the relationships are also important. In the past decade, ASEAN imports from China increased 3.6 times, at an annual average growth rate of $13.5 \%$ (Abbate \& Rosina, 2016, par. 3). From a business perspective, China wants a good political climate to secure investment returns. From an economic perspective, stability in the China-ASEAN region means long-term mutual economic benefits. Finally, from a political standpoint, obtaining diplomatic support from ASEAN is critical to China's sense of security on its east, since Japan and Korea are long-term allies of the U.S.

Counterbalancing the U.S.'s "Asia Pivot" by retreating to the west

As China rises as a global power, it finds the U.S.'s influence in Asia troublesome. The U.S. has military presences in Afghanistan, Uzbekistan and Tajikistan and has recently strengthened ties with South Korea, Japan, India, and Vietnam. These circumstances have given China more a reason to believe in the "China containment policy", an officially denied but frequently claimed goal of the U.S.'s foreign policy. Such logic was reinforced when the Obama administration introduced its "Asia Pivot" strategy in 2012 and Vietnam and Philippines became more aggressive in their territorial claims in the South China Sea.

Given the U.S.'s current economic and political strengthen, it is unwise for China to challenge the world's super power directly (D. Chen, 2014, par. 7). To mitigate the negative effects from potential encirclement on its east, China has to find alternative paths to reach other parts of the world. The design of OBOR, the "Belt" that connects the Eastern China to Venice, and the 
"Road" that brings China to the same destination through a seaborne route, reveals that OBOR is China's strategic retreat to the west.

Securing Strategically Important Natural Resources and Trade Routes

Securing Strategically Important Natural Resources

China's hyper growth over the last decade necessitated its search for energy resources at home and overseas. The following analyses will use data compiled by the American Enterprise Institute (Scissors, 2017) to compare China's investments and construction activities (referred to as "I\&C" going forward) ${ }^{16}$ overseas pre- and post-OBOR and see whether the strategy has noticeably shifted these resource-acquiring activities to OBOR countries.

Exhibit 5 shows I\&C in OBOR and non-OBOR countries from 2005-2016. While China largely invested in non-OBOR countries for energy resources pre-OBOR, the trend reversed after the strategy launched.

Exhibit 5: Chinese corporations invest more in OBOR countries' energy after 2013

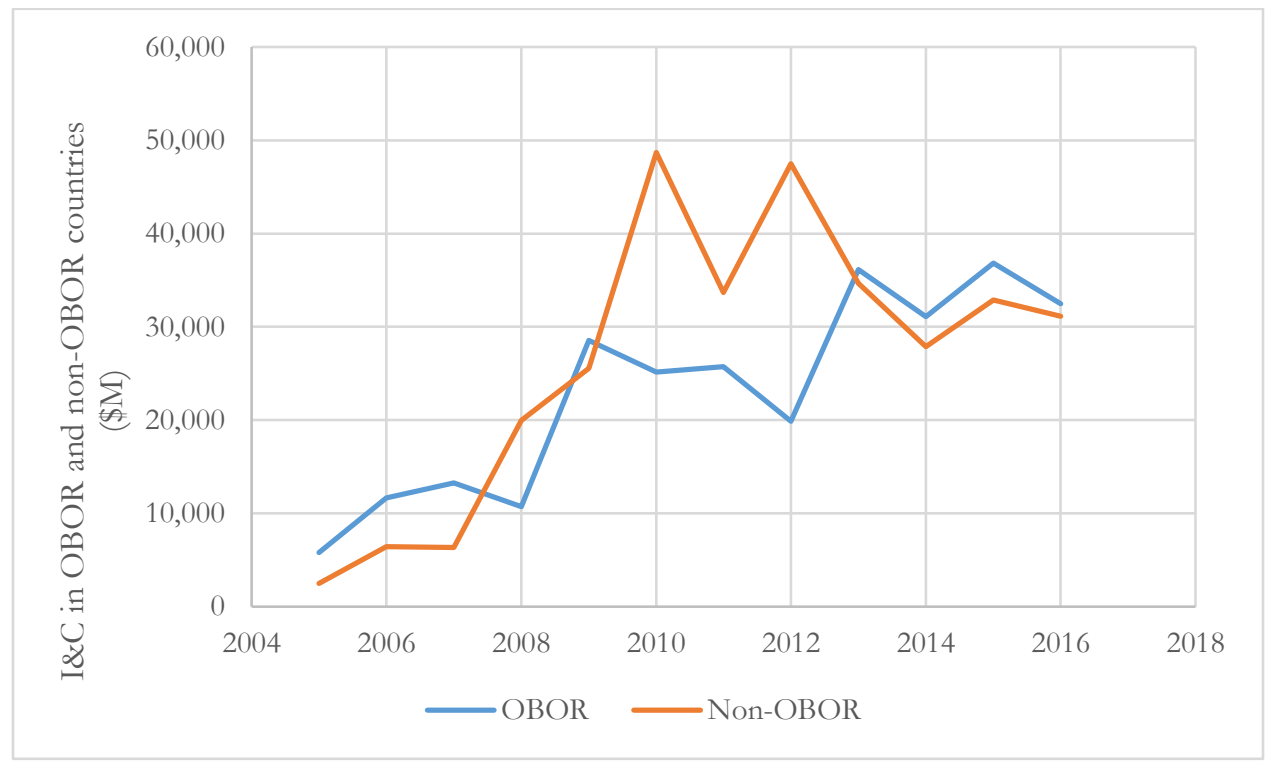

Since the launch of OBOR, Pakistan has been the grand project's most enthusiastic supporter while locking up a series of deals with China. Therefore, what China is investing in and constructing in Pakistan is instrumental in understanding whether China is using OBOR to acquire

\footnotetext{
16 The data include corporate investments and construction contracts with values above $\$ 100 \mathrm{~m}$ and does not include any
} type of loans. All the data were obtained from corporate reporting. 
natural resources overseas. The blue line in Exbibit 6 below shows energy I\&C in OBOR countries including Pakistan while the orange one represents that excluding Pakistan. Their difference after 2013 is striking. Exhibit 5 and Exhibit 6 indicate that OBOR serves China's interest to acquire strategically important energy resources.

Exhibit 6: IËC in Pakistan weights substantially in total OBOR I\&C

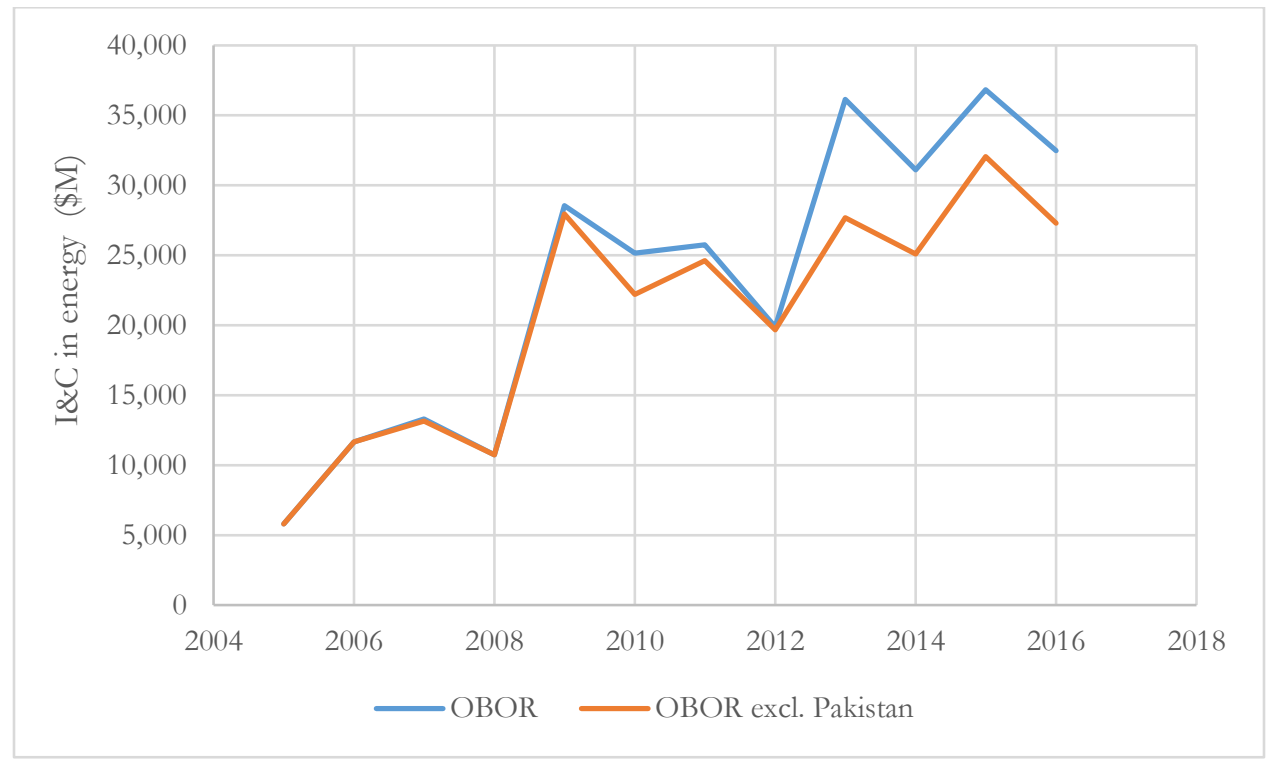

However, it is important to note that China's heavy investment in energy in OBOR region predated OBOR. In other words, the activities under OBOR are extensions of what China had already been doing before OBOR was conceived. In fact, China's I\&C in Central Asia dated back two decades ago when China National Petroleum Corporation (CNPC) made its first effort to search for upstream assets in Kazakhstan. The investments gained real momentum in the 2000s when China became increasingly concerned with its increasing energy demand due to its double-digit growth. In 2005, the Kazakhstan-China oil pipeline was put into operation. The Trans-Asia Gas Pipeline between China and Turkmenistan began deliveries in 2009 (Downs, 2015, p. 4). From late 2005 to 2013, China's investments in the Five Central Asian states continued to increase and they were overwhelmingly in the energy sector.

It is also imperative to note that China's I\&C in energy takes place in non-OBOR countries as well. In fact, although non-OBOR countries received less capital than OBOR ones from 2013 to 2016, the largest single energy deals were still found in non-OBOR countries. The largest single deal happened in Canada (\$15.1 billion in 2012), followed by Switzerland (\$7.2 billion in 2009) and Brazil 
( $\$ 7.1$ billion in 2010). In 2013, the year when OBOR was launched, Pakistan came to the top (\$6.5 billion), seconded by Kazakhstan ( $\$ 5.3$ billion). However, neither of them succeeded in defending their positions. In 2014 Ecuador ( $\$ 3$ billion), Australia ( $\$ 2.8$ billion), Italy ( $\$ 2.8$ billion) secured the biggest three deals from China. Pakistan dropped to the fifth, only receiving $\$ 2$ billion. In 2015 , China allocated the most capital (\$6 billion) to Malaysia's nuclear energy sector. However, this Southeast Asian OBOR country was followed by Argentina, Angola, Brazil, and Australia, which received $\$ 17.5$ billion in total, almost three times that of Malaysia. Pakistan dropped to the seventh on the rank. Finally, the largest single deal in 2016 went to Brazil (\$3.7 billion) in the hydro power sector.

Given these analyses above, we can arrive at the following three conclusions. First of all, while China's energy I\&C used to concentrate in non-OBOR countries, the launch of OBOR reversed the trend and shifted the weight towards OBOR ones (Exbibit 5). Second, China's energy acquisition activities in Pakistan, the most enthusiastic OBOR participant which locked up a series of deals since the launch of OBOR, indicate that natural resource acquisition is a top priority on OBOR's agenda (Exhibit 6). Third, even though OBOR increased China's I\&C in OBOR countries, China's resource acquisition activities in the region long predated OBOR. In other words, without OBOR, China would still have invested heavily in Eurasia's energy resources, though the amount would be lower. Finally, China's search for natural resources takes place in both OBOR and nonOBOR regions. In other words, OBOR is under a broad Chinese scheme of resource acquisition overseas.

\section{Securing Strategically Important Trade Routes}

The benefit of OBOR on China's strategic trade routes is clear. China's trade with the Middle East and Africa has been heavily depending on the sea. As a result, secure access to the Indian Ocean is imperative. However, China has been concerned with its access to the Malacca Strait, a narrow stretch of water between the Malay Peninsula and the Indonesian island of Sumatra. Controlled by Singapore, the water is where $82 \%$ of China's maritime oil imports and $30 \%$ of its maritime natural gas imports transit (Bender \& Rosen, 2015, par. 9). It is also part of the sea lane where Chinese cargo ships must pass to reach Africa's east coast (The red arrows in Exhibit 7). 
Exhibit 7: China's seaborne transport route through the Malacca Strait and alternatives through new ports

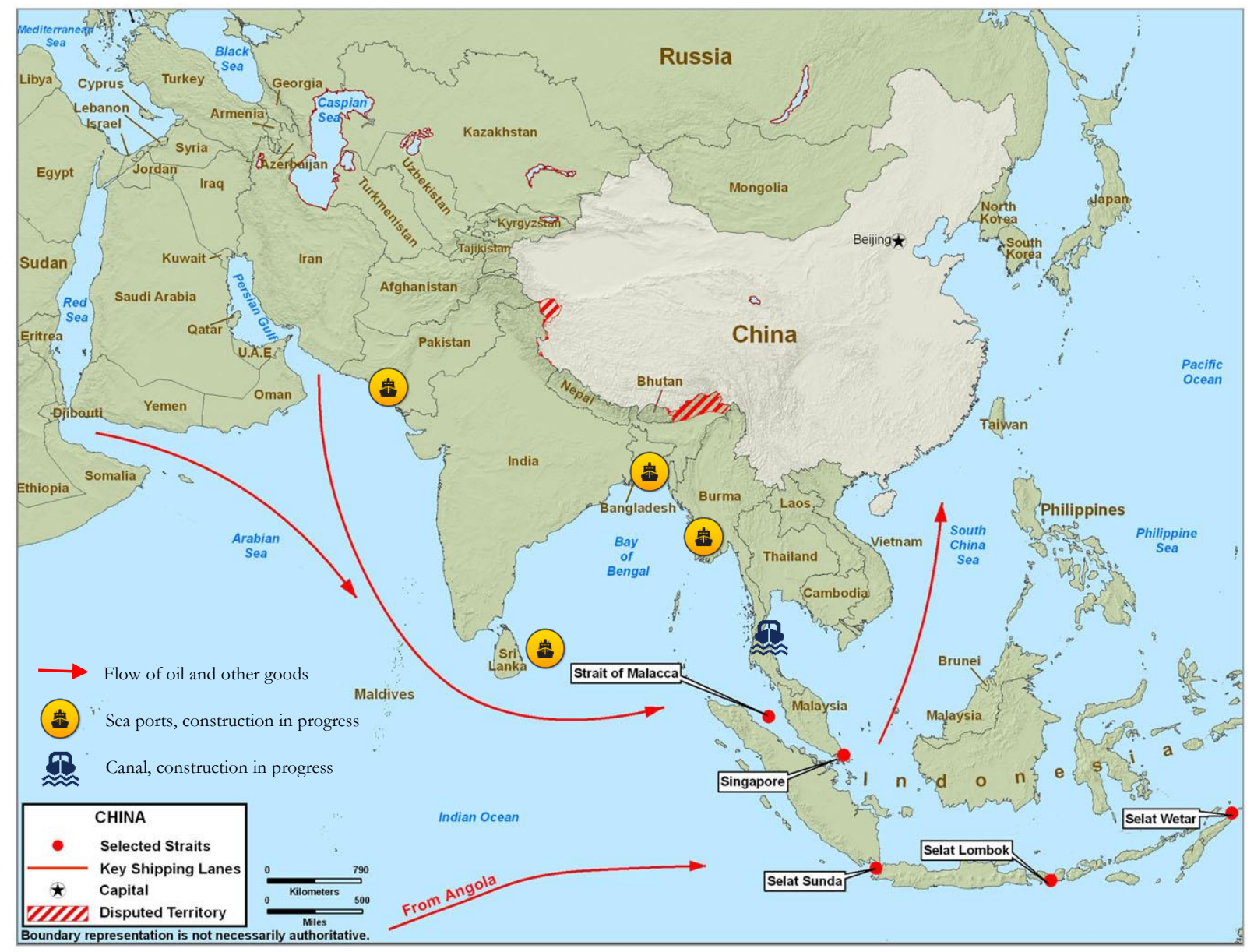

Source: Indian Defense (modified)

Chinese leaders have being viewing the Malacca Strait as "a strategic vulnerability" and a Chinese press declared that "It is no exaggeration to say that whoever controls the Strait of Malacca will also have a stranglehold on the energy route of China” (Storey, 2006, par. 3). Beijing has always been uneasy about the greater roles some external powers have been playing in the region such as the U.S. In regardless to how much the U.S. politically influence the three littoral countries surrounding the strait, Singapore, Malaysia and Indonesia themselves already pose the possibility of a potential sea route blockage if their relationships with China worsen. China has also been observing India's enhanced presence in the area. In addition to the risk embedded in China's relationships with its neighbors, the Malacca Strait is subject to privacy and terrorist attacks as well. There are simply too many built-in vulnerabilities in the sea route and it would cause endless disturbance to the big oil importer (Storey, 2006, par. 5). 
To secure access to the Indian Ocean, China has to either carefully nurture its relationships with the countries surrounding the strait or try digging new paths for its cargo ships to reach the Indian Ocean. The design of OBOR takes care of both. The economic promise ensures that Malaysia, Indonesia and Singapore will at least consider the consequences of disturbing China's cargo ships from passing. However, the more important design of OBOR lies in its seaborne corridor. In the name of the 21st Century Maritime Silk Road, China has been building deep sea ports in Myanmar and Bangladesh in addition the high-profile Gwadar port in Pakistan. It even invested \$1.4bn to build an entire port city (Colombo Port City) in Sri Lanka (Shapard, 2016, par. 2). In addition, it has been trying to convince Thailand to construct the Kra Canal that would connect China to the Indian Ocean through the Andaman Sea and the Gulf of Thailand. As Exhibit 7 shows, China has been building a series of sea ports and a canal that allows it access to the Indian Ocean directly or at least indirectly.

Again, we need to keep in mind that China's search for alternative trade routes already took place long before the launch of OBOR. In 2003 former Chinese President Hu Jintao proposed "the adoption of new strategies to mitigate the perceived vulnerability" (Storey, 2006, par. 3). The proposal for building the Kra Canal in Thailand predated 2006. The construction of the Colombo Port City began in 2011 but was later rebranded under OBOR. Therefore, the real question is why China suddenly began to brand the investing activities that existed a long time ago.

In conclusion, OBOR directly pumped up China's energy investment and construction activities along the Belt and the Road. The strategy is also China's effort to seek alternative trade routes that would secure China's control of where its energy resources transit. Nevertheless, we should not overlook the fact that many of the activities with OBOR characteristics can be traced back to at least a decade ago. The key question we should ask about OBOR ultimately lies in why China would like to let its investment projects wear an OBOR hat and why such behavior is observed in Eurasia instead of in Africa or Latin America, two other regions comprising 10\% and $17 \%{ }^{17}$ of total Chinese corporate resource acquisition activities overseas.

\footnotetext{
${ }^{17}$ Computed using data from the American Enterprise Institute (Scissors, 2017).
} 


\section{Establishing a "Community of Interest" under the Chinese Leadership}

The design of OBOR is intentionally redundant, with the "Belt" and the "Road" leading to the same destination. This ensures that there is flexibility when China wants to reach other Eurasian countries, meaning it can turn to alternative routes while bypassing regions that are temporarily unpassable. The design also ensures that the interactions between China and countries along the routes are two-way: critical resources such as energy and metals can flow to China while China's political influence flow to the west along with its capital. Such economic and political mutuality will naturally cement relationships between China and OBOR participants and serve as the architecture of the "Community of Interest" that OBOR aims to build. Such Community ensures that China's interest in critical resources can be served at a regional level. It also means that China can have more say in regional issues. With countries bonded by ties in economy and regional security, it will be hard for external power to exert influence upon the region. 


\section{China's Foreign Policy as a Continuum}

Those who claim that OBOR will or will not have an impact on China and Eurasia both have failed to treat OBOR as an organic part of China's foreign policy. This research argues that OBOR has manifested China's principles and consistency in its foreign policy to a large extent. The rationale of the policy is rooted in China's ideology, philosophy and the significant historical events that its people have been through, many of which traumatic. Although such foreign policy has evolved and been adjusted, it has not digressed from the core.

Three important characteristics in China's foreign policy or diplomatic means are relevant to this research in analyzing OBOR. First, one element of OBOR, "going out", has been China's strategic priority since former Chinese president Deng Xiaoping opened up the nation in 1979. Second, China's foreign policy is realistic and pragmatic. Third, stemming from political pragmatism, China's foreign policy is always a direct and practical response to the country's domestic needs, in contrast to that of the U.S., which is frequently based on political ideals and the economic situation these ideals will being in the long-term. Finally, "non-interventionism" has been the quintessential pillar supporting China's foreign policy. Nevertheless, as China gets itself increasingly involved internationally, adherence to this principle becomes challenging. The following section will illustrate the origin, principle, and evolution of these characteristics of China's foreign policy above in detail.

\section{Characteristics}

"Going out"

"Going out" is China's strategy which encourages its enterprises to invest overseas. It was made in 1999 with an origin that can be traced all the way back to 1979, when Deng Xiaoping "opened up" China and cautiously tried integrating it into the global economy. At that time, only selected state-owned enterprises were allowed to set up international branches and invest overseas. More than a decade later China incorporated enterprise internationalization as a national economic development policy. In 1999 the term "going out" was officially brought to the table, which was then formalized within the $10^{\text {th }}$ Five-Year Plan as a central directive in 2001. Overseas direct investment in selected industries and activities was actively encouraged, especially those with potential for exports. The post-WTO China saw heightened competition in different industries in domestic markets and this further incentivized companies to seek new markets abroad. Over the 
past decade, the strategy became fixated around acquisitions of natural resource by state-owned enterprises such as CNPC, Sinopec, CNOOC and Chinalco.

Two key factors promoted China's "going out" since the turn of the century. First, China's export-intensive economic structure accumulated huge amounts of foreign reserves. This put upward pressure on the foreign exchange rate of RMB. In response, China encouraged the acquisition of assets overseas. Second, when China joined the WTO, it foresaw increased competition in domestic market due to the inflow of foreign goods, services, and enterprises. This pressed China to try to equip domestic firms with international experience to stay competitive. Also, the increased competition made it increasingly hard for enterprises to maintain profitability at home and Chinese enterprises could be better off looking for markets overseas. Finally, China's "victim mindset" as a result of the memory of being invaded and humiliated by the western powers and Japan alerted Chinese leaders to push companies and talents out. After all, the decline of imperial China's competitiveness started when rulers of the Ming and Qing dynasties intentionally secluded the country from the outside world, claiming that "China is sufficient in everything (tian chao wu chan fengying, wu suo bu you)".

Keeping in mind the history and evolution of Going Out in mind, it makes sense for us to see China's global investments began to increase steadily long before the launch of OBOR. Although OBOR's objectives go beyond purely making more investments and focuses on the “integration" of Eurasia's economy, OBOR still finds its roots in Going Out. This confirms that OBOR stems from China's national strategy and foreign policy formulated almost two decades ago, although it did evolve.

Political realism and pragmatism

Literatures on China's foreign policy largely characterized it as "realistic" and "pragmatic". As Lampton (2014, p. 164) put it: "The reflex in the Chinese system is to ask what global developments imply for China rather than to contemplate how China can change the world...China doesn't want to establish a new world order; it wants to get stronger in the existent world order. All powers have a stake in the world order" (Lampton, 2014, p. 108). Although often regarded as "nonconformist" to the existing world order, what China truly rejects is international systems dominated by the U.S. where China does not have a say. It "accepts the economic and social structure of the international system and universalistic character of the UN-oriented international security system, as 
well as the regimes in which it has negotiated membership" (p. 231). This is confirmed by China's increasing engagement in the UN-led international security system in the past decade. This is why China keeps highlighting that OBOR is consistent with the UN Charter and promoting OBOR as an "alternative" to the existing international cooperation models. Although many remain skeptical about China's claim that OBOR is "open" and "ideology-neutral" in nature, the paragraphs below by Lampton confirm that such these claims have strong foundations in China's foreign policy.

In 2013 there are high-ranking people and opinion leaders in and out of government in the PRC who argue that China's future global status and role rest on aligning the country more closely with global norms and who do not simply dismiss the call for universal values as capitulation to "westernization." China still is debating whether and how to adopt universal values - something America did long ago, asserting that its own values were universal values (p. 229, par. 2).

Americans generally describe the making of their foreign policy as a ceaseless quest to balance America's interests with its values [what the Chinese often refer to as "ideology"] security, material, and power needs against more intractable ideas of "right" and "wrong." Americans often (hopefully) assert that to serve their values is to pursue their interests (Lampton, 2014, p. 109, par. 2).

There is, therefore, an intrinsically interventionist quality to U.S. foreign poly, with the strength of this impulse varying as the burden of prior efforts become more or less distant in the collective consciousness. Interventionist and isolationist impulses coexist in American foreign policy psyche (p. 110, par. 1).

China's foreign policy view is pragmatic and seeks to maximize benefits in an every changing yet interconnected global environment. It is not a view grounded in absolute values $-i$ is situational ethics on global scale (p. 110, par. 2).

Foreign policy as a direct reflection of domestic concerns

Unlike the U.S., which sometimes takes actions based on ideological beliefs such as liberalism, democracy, and human rights, China's foreign policy always reflects its pressing domestic interests. This is a manifestation of China's political pragmatism. Because of China's vast landmass, large population, and diverse demographics, problems facing domestic leadership are complex enough to keep them from worrying too much about activities of the U.S. or any other country beyond Taiwan, Tibet, and China's peripheries. External movements only become relevant when they start to threaten China's domestic stability and the legitimacy of the ruling party (Lampton, p. 141, par. 1). The director general of Beijing ministry commented in 2005: "We think about China, 
not the U.S. We tell the U.S. to do its thing and China will do its peaceful development...Do your own thing and leave us alone" (p. 231, par. 3).

Non-interventionism and ideology-neutrality

China's emphasis on the sanctity of state sovereignty and non-interference in the internal affairs of other countries dates back to the Indian-Chinese Trading Treaty signed in 1954. Several factors led to this policy. First, non-interventionism supports state sovereignty against foreign intervention, which China generally sees as western imperialism. This preemptive moral defense is very important to China. After the trauma from the Century of National Humiliation ${ }^{18}$, it has to make it clear that future intervention is morally wrong and condemned. A more practical thinking behind the principle is that China needed to reach out to other Asian countries for diplomatic relationships after its establishment in 1949, and non-interventionism provided convenience for it to cooperate with countries with different political systems and ideologies. Therefore, noninterventionism is a product of the China's political realism and a practical attitude in dealing with international events.

China has been sticking to the principle throughout the years after its proposal and today still adheres to its core and the principle continues to bring China diplomatic convenience. Today China reaches out to countries for supply of energy and other natural resources. Non-interventionism alleviates political worries of these countries and helps China to articulate that its activities would be purely commercial. The benefits this principle is evident in many cases. For example, by being purely commercially motivated and clearly communicating such intention, Chinese people in Afghanistan are better received than American ones. While China was able to secure multi-billion projects from the Afghani government, gaining privilege in accessing the country's rich mineral raw materials, the U.S.'s involvement in the country's domestic affairs, especially the infamous war, makes commercial considerations unwise, as critics would accuse the U.S. of waging war to capture the country's mineral wealth (Wines, 2009, p. 19).

Although China tries to be firm on non-interventionism, its increasing international presence has challenged this effort. The cases besting illustrating this point are in Africa. In 2009, China passed the United States as Africa's leading bilateral trading partner and has subsequently widened

\footnotetext{
18 The Century of National Humiliation, or "the Hundred Years of National Humiliation", refers to the period of intervention, invasion, and imperialism by Western powers and Japan in China between 1839 and 1949.
} 
the gap. In recent years, China has become one of Africa's largest source of annual foreign direct investment. It is an important provider of aid. It is estimated that one to two million people of Chinese origin now live or work in Africa. As a result, Chinese nationals and interests increasingly must deal with African countries' internal conflict. Even if it is willing to forgo economic interest in these countries during crisis to stay non-interventionist, it is impossible for it to stay out of the hostile events involving Chinese personnel endangered by kidnappings, killings, and evacuations, which happened in Sudan, South Sudan, Nigeria, Ethiopia, and Libya (David, 2014, par. 2).

Such cases were seen since 1990 s when China began to actively participate in UN peacekeeping operations. In 1992, a famine broke out in Somalia while the country's internal conflict had made UN's humanitarian efforts increasingly difficult. In response UN established an international coalition that provided security for humanitarian organizations. China shied away from joining the coalition. However, it voted for the UN's resolution authorizing military force. Its rationale was that this was "an exceptional action" and "unique situation." Nevertheless, although China's veto made it sitting on the fine line between intervention and non-interference, it did not go further. When UN issued another resolution to fight the Somali warlords, China abstained (David, 2014, par. 3).

Usually, China would show a bit more flexibility about UN's resolutions containing intervention when the impacted state's authorities or major organizations concurred. Without positive attitude towards external intervention from the impacted state, China would be critical of use of external force. However, China slightly deviated from such behavior during Libya's crisis in 2011. In response to Libya's trouble, the UN Security Council's resolution 1970 imposed an arms embargo on Libya and banned members of the al-Qadhafi family on travelling. China voted for the resolution but abstained on the subsequent UN Security Council resolution 1973, which authorized a "no fly" zone over Libya. China criticized that some elements of the resolution went against its policy to respect "sovereignty, independence, unification and territorial integrity of Libya." Nevertheless, China did not veto the resolution, indirectly allowing the Security Council to authorize the use of force under without the consent of the impacted state. The case in Libya thus marked a slight yet important shift of China's interpretation of non-interventionism. Many observers thought that China's vote for, and then abstention from, UN resolutions supporting limited intervention in Libya was a turning point. However, although challenging to maintain, Beijing shows no intention to walk away from it and strives to prevent the making of another Libya. This is evident in its treatment 
to the crisis in Syria. Since the country in the Middle East broke down in war in 2011, China has vetoed a series of Security Council resolutions, citing its non-interventionism (David, 2014, par. 5).

China's policy in Sudan and South Sudan offers the strongest evidence of a change in its approach to non-interference in Africa. The China National Petroleum Corporation has a 40\% stake in the consortium that developed Sudan's oil sector. Chinese companies built the pipelines, oil terminal and most of the oil infrastructure for the industry. At the peak of Sudan's production, China obtained about $5 \%$ of its imported oil there. China is also one of the principal suppliers of arms to Sudan.

China's first challenge was responding to the crisis in Darfur, which resulted in growing Western and some African criticism of the Omar al-Bashir government in Khartoum, a regime with which China had close relations. Initially, China supported Khartoum in opposing both a UN peacekeeping mission in Darfur and the desire by most southern Sudanese to hold a referendum on possible secession. China abstained on a series of UN resolutions calling for sanctions against Khartoum. By late 2006, however, with an eye on holding a successful Olympics in Beijing, China began methodically to change its position on Darfur. In 2007, China's ambassador to the United Nations announced that China had told Sudan to accept the UN-African Union peacekeeping mission in Darfur. The ambassador added that China "never twists arms," but Sudan "got the message." 
When this happens, it tends to concur on the basis of responsibility to protect. China is also more likely to be flexible about intervention is regional organizations show desire to intervene. This shows that China has taken a slightly different interpretation on this core foreign policy principle and from time to time it is conflicted within.

According to China's behaviors in Africa, we can project China's deployment of noninterventionism in OBOR. Its track record suggested that China is more flexible about UN's or local organizations' intervention in the impacted nations or regions when there are justifiable humanitarian and moral concerns. It will also allow intervention when its abstention would have substantial impact on its imminent international activates. In addition, China is more likely to allow intervention when it has substantial economic interest in the impacted state or region. All of these conditions are built-in in OBOR's design and OBOR participants' political status quo. Therefore, although China still honors its commitment to respecting national sovereignty, under OBOR, it inevitably has to deal with situations where it is inclined to allow intervention.

\section{OBOR as an Extension of China's Foreign Policy and international role}

This research argues that OBOR is largely an extension of China's existing foreign policy and national strategies. "Going out", non-interventionism, ideology-neutrality, mutual benefits, and inclusiveness are all principles or characteristics in China's international involvement that can be traced back all the way to the 1950s. However, although OBOR does not show China's digression from any of the characters aforementioned, it does reveal the evolution in the country's foreign policy. From its international self-positioning as "keeping a low profile (tao guang yang hui)" under Deng Xiaoping to "China's peaceful rise (zhong guo de he ping jue qi)" under Hu Jintao, and finally to "striving for achievement (fa fen tu qiang)" under Xi Jinping, China is now eager to take on greater leadership in the Eurasian region, advocating for a "Community of Interest" under OBOR. The most significant aspect of OBOR lies in China's action of branding its regional activates under OBOR: China is now articulating its will and commitment to be a regional power leading shaping Eurasia's regional economic integration and political coordination. In fact, even if China does not 
want to be a hegemon, as it taps deeper into the areas on its West, it will inevitably need to address the risk in regional security in the region. Its economic commitments in Eurasia alone make it impossible for it not to take on strong leadership. 


\section{Case studies}

The scope of OBOR is extremely broad and the backgrounds of its participants are extremely diverse. OBOR's progress, impact, and the obstacles it encounters in each country differ. Therefore, it is necessary to examine OBOR's activities in different countries case by case. This research will conduct case studies on three countries: Pakistan, Kazakhstan, and Vietnam.

Pakistan

As Pakistan spent heavily on bridges, dams, and power plants in the past several years, steel consumption has been increasing by 6 to 7 million tons a year (Jamal, 2016, par. 8). The country's surging domestic demand for steel increased Pakistan's steel import from China in 2016 by a stunning 22\% (par. 19). The Central Asian state projects that domestic steel consumption will continue to surge due to the construction of the China Pakistan economic Corridor (par. 9).

According to the World Steel Association (2016, p.58), imports of semi-finished and finished steel products increased noticeably from 2013 to 2014 and skyrocketed after 2014 (Exbibit 8). Compared with the level in 2012, Pakistan now imports 75\% more semi-finished and finished steel products. China has been Pakistan's main source of steel products due to their competitive pricing. Therefore, it is safe to say that surge in steel import will pull up China's steel export to Pakistan. Thus, OBOR in Pakistan has contributed to alleviating China's excess capacity in steel. As infrastructure construction also demands other industrial products such as flat glass, electrolytic aluminum, etc., it is likely that OBOR in Pakistan helped to mitigate China's excess capacity overall. 
Exhibit 8: Pakistan's steel import surged after 2013

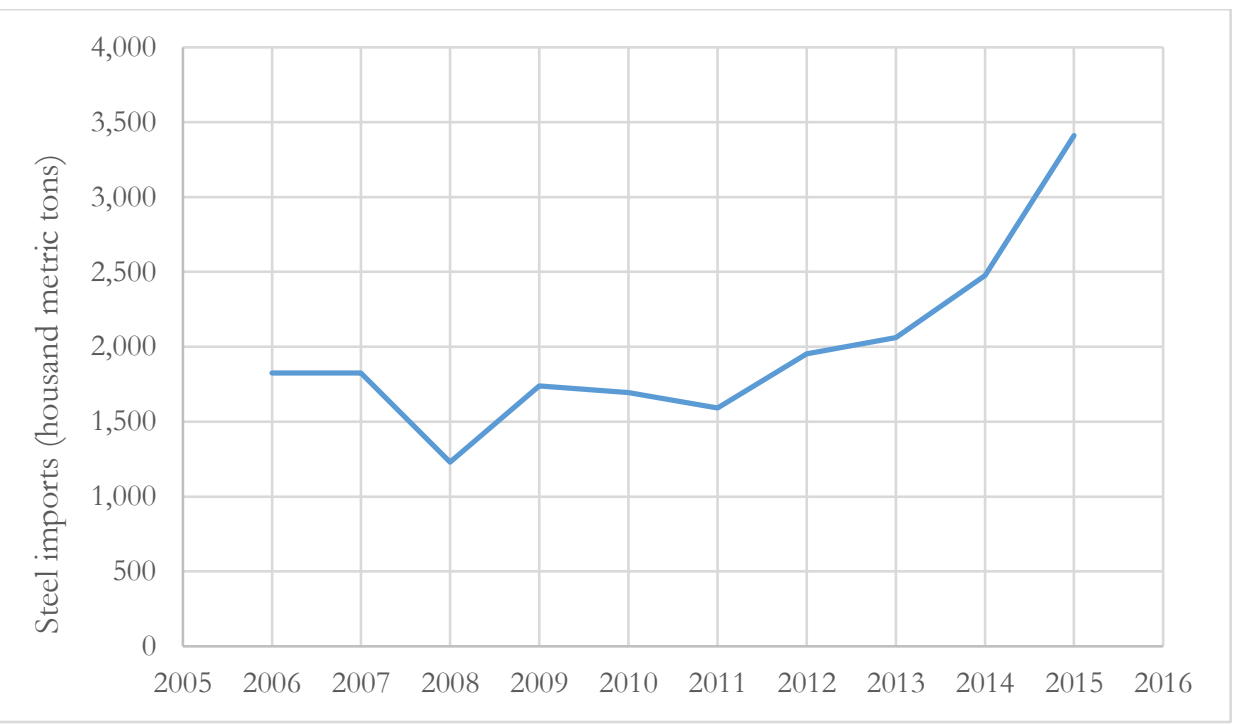

China's I\&C in Pakistan has been increasing almost linearly since a decade ago. While it slightly flattened after 2010, the launch of OBOR pushed it up again noticeably. According to data from the American Enterprise Institute (Scissors, 2017), in 2016, China's corporate investments and construction contracts in Pakistan reached $\$ 240$ bn, making up $45 \%$ of the total in OBOR countries.

Exbibit 9: Chinese corporate I\&C in Pakistan increased after 2013

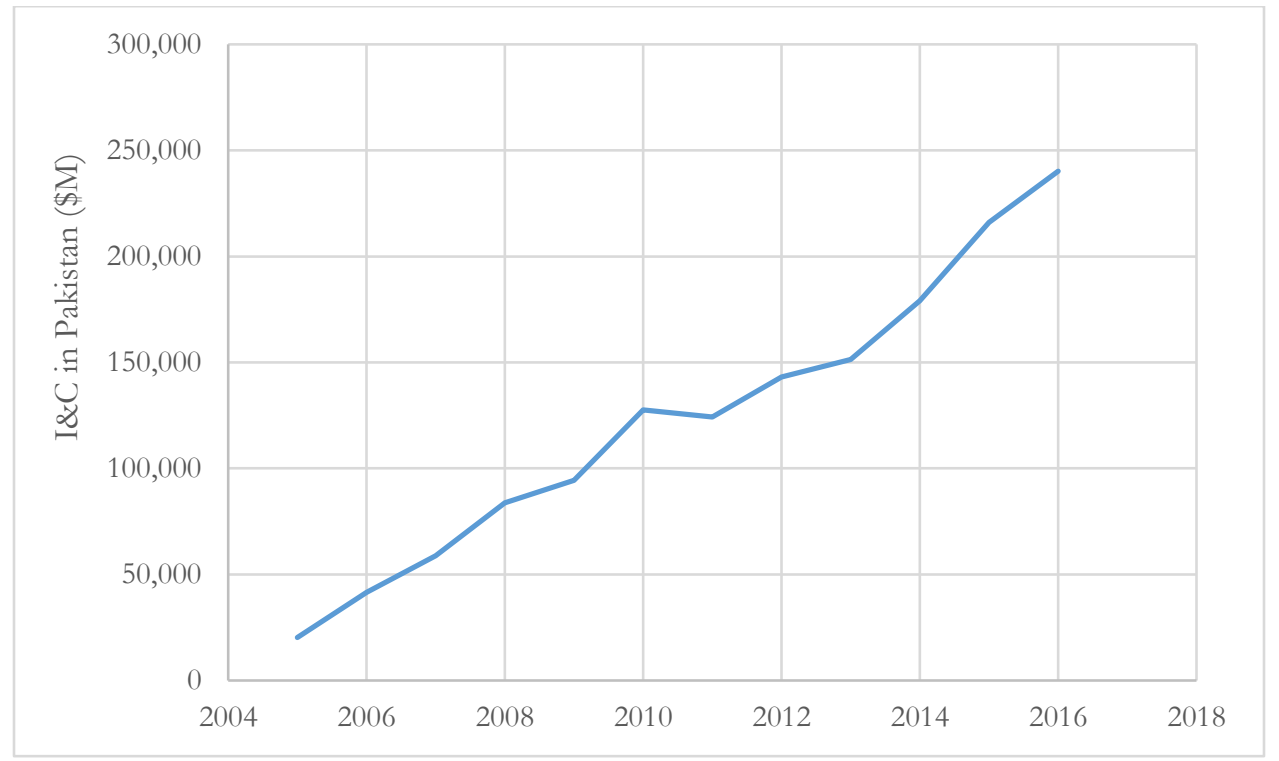


While China's total I\&C in Pakistan saw a slight surge as a result of OBOR, I\&C in energy skyrocketed from $\$ 200$ million in 2012 to $\$ 8.5$ billion in 2013 (Exhibit 10), though it quickly declined one year after to $\$ 6$ billion and $\$ 5$ billion in 2015 and is currently stable at that level with a slight upward trend. Although China's allocation of I\&C funds in the energy sector varied greatly from year to year in Pakistan, OBOR's impact on China's energy acquisition in Pakistan is beyond doubt.

Exhibit 10: China's corporate I\& C in Pakistan energy surged after 2013

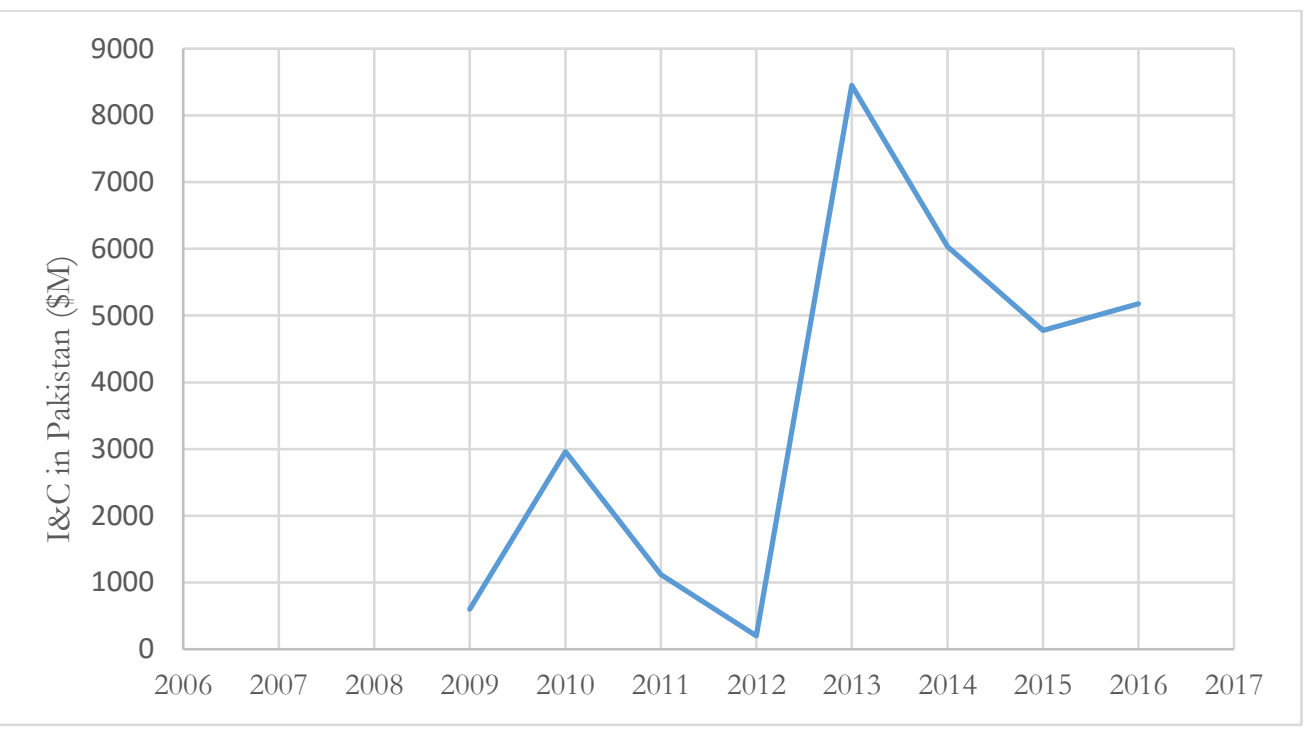

Political implication

The Sino-Pakistani relations have been tightening in recent years due to a range of factors. First, Pakistan perceives the growing convergence of strategic interest between the U.S. and India as a threat to its national security. Second, it opposed the U.S.'s unilateral military activity inside its territory. Since the announcement of OBOR, Pakistan has been a committed participant. This further strengthened its relationship with China. Going forward, the deep economic tie plus the strategic interest will likely bind the two countries together.

As Pakistan is committed to becoming China's ally, the geopolitical benefits China would receive from the China-Pakistan Economic Corridor (CPEC) are becoming increasingly clear. With the official opening of the Gwadar Port and the quick progress of CPEC's construction, China can already bypass the Malacca Strait and access the Arabian Sea and Indian Ocean through its Xinjiang Province and Pakistan. This enables China to transport its oil imports from the Middle East and 
conduct trade with Africa through a more convenient and secure sea route. Therefore, Pakistan, with CPEC and the Gwadar Port, is an important OBOR participant that helps China to secure strategically important resources.

\section{Kazakhstan}

Kazakhstan was where Chinese President Xi Jinping unveiled OBOR in 2013. In 2014, Kazakhstan announced its own $\$ 9$ billion infrastructure development plan "Nurly Zhol" ("the Bright Path"), which is often regarded as a direct response to OBOR. Given this, we would assume that Kazakhstan's imports of industrial products from China would increase. However, this is not the case. Exhibit 11 shows that imports of semi-finished and finished steel products in Kazakhstan have been decreasing since a decade ago. While Kazakhstan imported nearly 3 million tons semifinished and finished steel products in 2007, nine years later the volume shrank by more than fourfifths. The sharp decrease was largely due to the burgeoning Kazakh steelmaking industry. As overall steel imports in Kazakhstan declined, those from China would decrease along. Therefore, OBOR in Kazakhstan did not bring China relief in terms of its excess capacity in steel.

\section{Exhibit 11: Kazakbstan's imports of semi-finished and finished steel products decreased in the last decade}

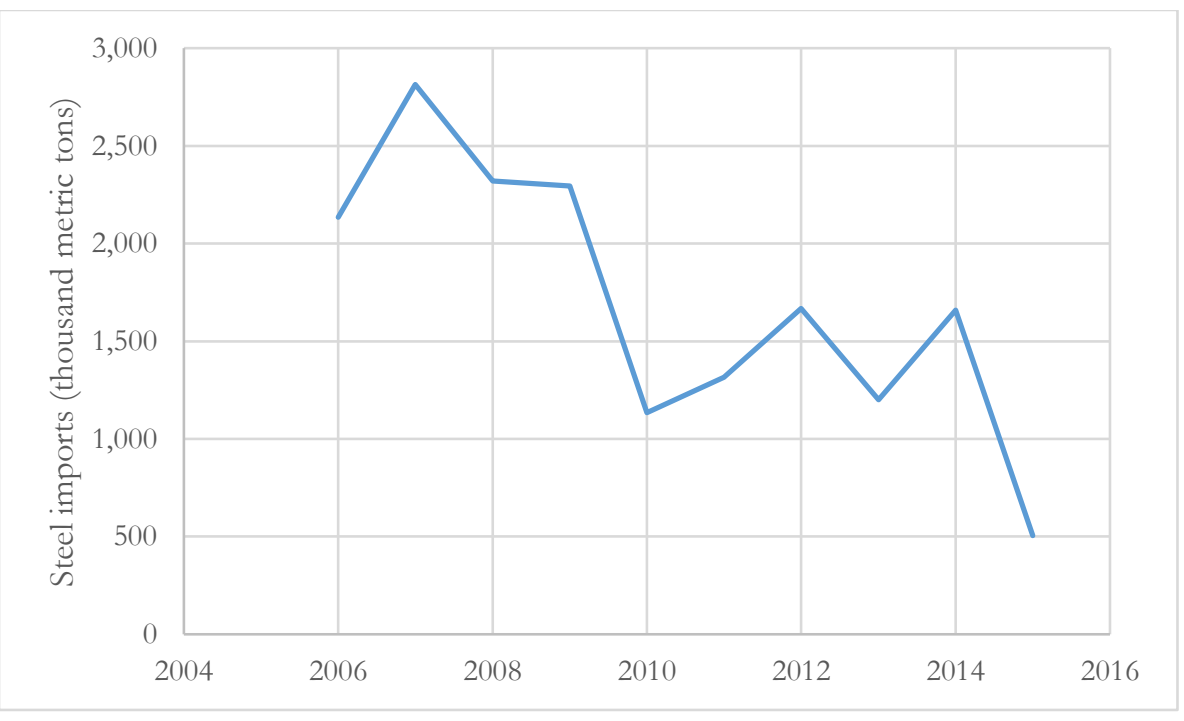

The launch of OBOR galvanized energy I\&C in Kazakhstan. As Exhibit 12 shows, total I\&C in Kazakhstan reached an all-time high of $\$ 5.3$ billion when CNPC Exploration and Development Company Ltd (CNPC E\&D) purchased 100\% stake in KazMunayGas (KMG). This single 
investment was worth more than the previous four years combined and $26 \%$ more than the second highest investment of all time, which took place in 2005 when China National Petroleum Corp (CNPC) acquired PetroKazakhstan (PK) for $\$ 4.18$ billion. However, energy I\&C in Kazakhstan varied greatly year by year, and the amount was either very low, below $\$ 530$ million, or astonishingly large, reaching several billions. This is because I\&C in the country often took the form of state-run Chinese energy companies acquiring a substantial number of shares, or simply all shares, of major Kazakh energy companies. For example, besides the two largest deals in 2005 and 2013 aforementioned, the third largest deal took place in 2009 when CNPC acquired MangistauMunaiGas for $\$ 2.6$ billion. Among the 29 I\&C deals China made with Kazakhstan since 2005, two thirds of them were in the energy sector, making up over $80 \%$ of total I\&c. This makes it more than clear that China's stake in Kazakhstan lies in its energy and such interest grew stronger after 2013.

\section{Exbibit 12: I 6 C in Karakbstan peaked in 2013}

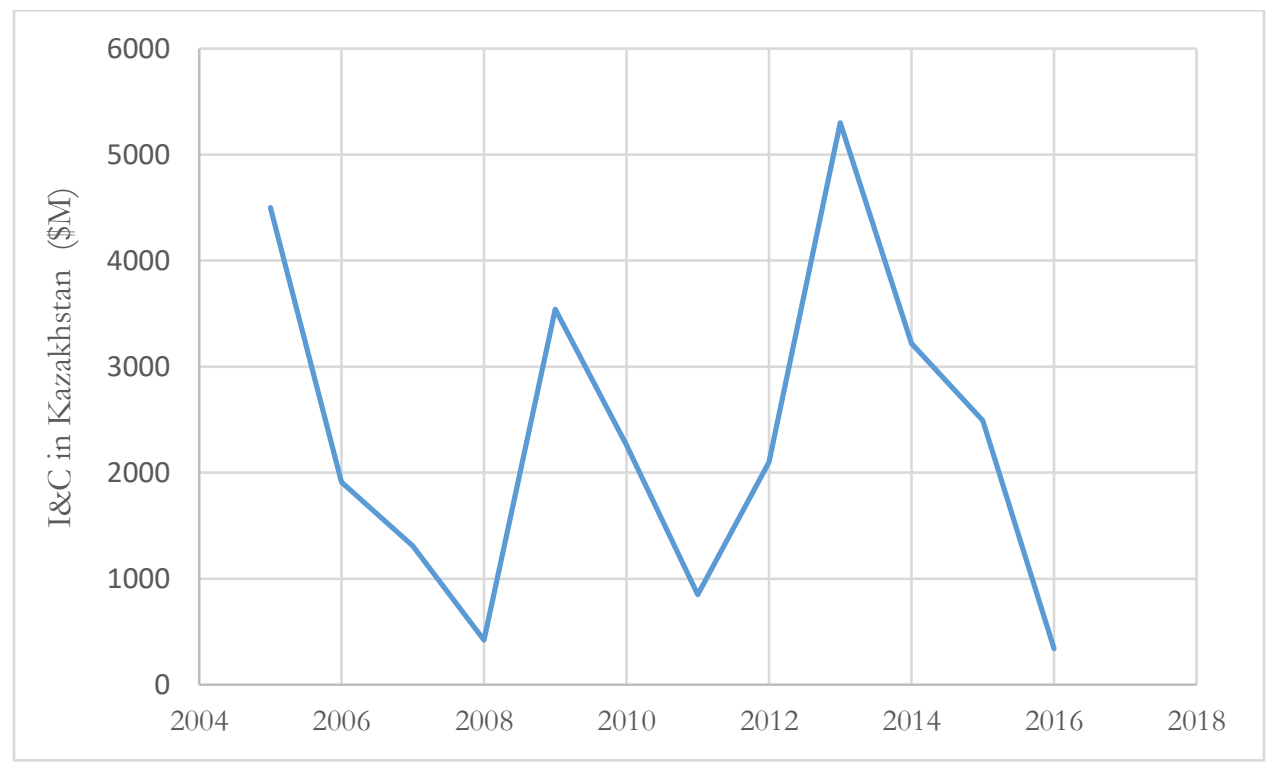

China's relations with Kazakhstan are determined by factors beyond economic ties. The two Asian countries' strategic interests are quite compatible. China has to transit through Kazakhstan to reach Europe by land and Kazakhstan wants to modernize its infrastructure. Since OBOR was announced, Kazakhstan quickly assigned its national development goals with the goals of OBOR, including "the 2050 Strategy", "the 100 concrete steps" (Frolovskiy, 2016, par. 2) as well as the aforementioned "Nurly Zhol". While China is devoted to building the "Belt", Kazakhstan is busy 
constructing "special economic zones" which includes cargo hubs that will serve to transit OBOR's goods and services. In fact, Cargo trains have already begun running from China to Iran via Kazakhstan and Astana. The alignment of the two nations' strategic interests make it the high time for them to cement their relationship.

Vietnam

As Exhibit 13 shows, Vietnam's steel imports skyrocketed after 2013. As China has historically been Vietnam's top source of steel imports, Chinese steel exports to Vietnam surged along. In 2016, China's steel exports to Vietnam made up 13\% of its total steel exports that year (9.2 million metric tons), up by an astonishing $24.8 \%$ from the previous year (International Trade Association, 2016, p. 3).

Exhibit 13: OBOR increased Vietnam's steel imports

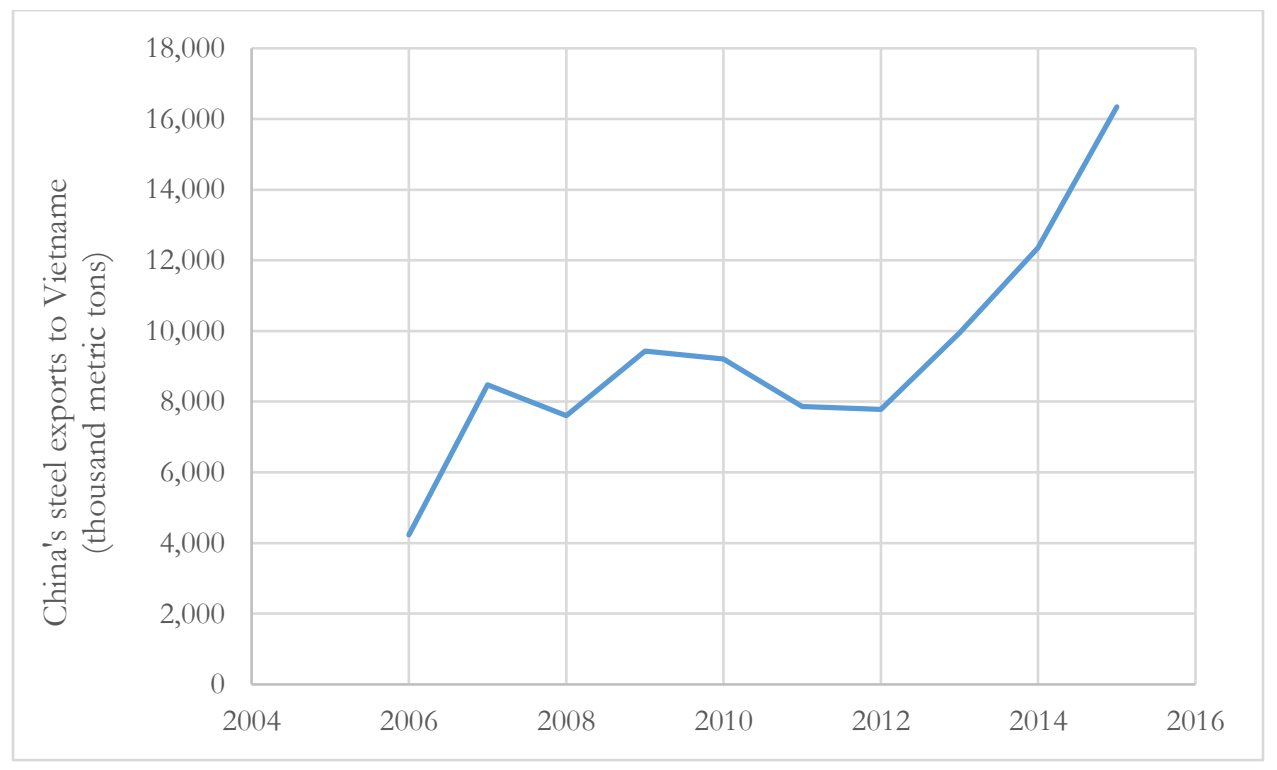

Nevertheless, OBOR did not have similar impact on I\&C in Vietnam, which peaked in 2010 when China's state-run enterprises engaged in seven transactions with Vietnam concentrating on the energy sector (coal and hydro). Since then, the yearly amount slid quickly to almost zero in 2014. The investment rebounded in 2015 but again decreased to an ignorable amount in 2016. 
Exbibit 14: I 2 C in Vietnam peaked in 2010 and then declined drastically

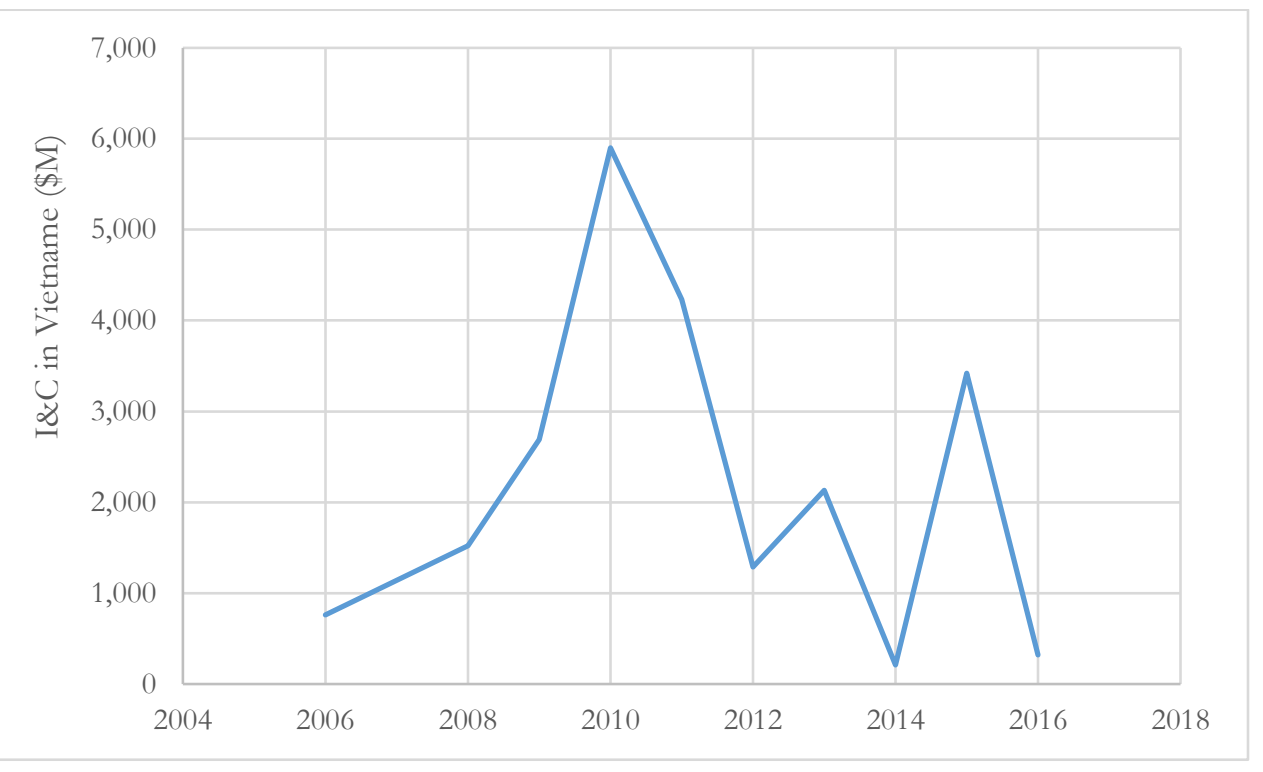

The Sino-Vietnamese relations is a precarious one. While the Chinese and the Vietnamese celebrate shared cultural origins, Vietnam is wary of its neighbor's rapid growth in economy and political influence. The two Sino-Vietnamese wars fought in 1979 and 1988 further added to such insecurity. Such victim mindset forced Vietnam to quickly mobilize when China began to intensify its activities in the historically disputed Paracel and Spratly Islands. After 2009, Vietnam's challenge to China's claim on the South China Sea became public. China showed increasing aggression in response while repeatedly detaining Vietnamese civilian boats in disputed waters and even attacking them. The Sino-Vietnamese territorial conflict culminated in 2014 when Beijing deployed its oildrilling rig, Haiyang Shiyou 981 (HD-981), in waters not that distant from Vietnam's coast. Feeling seriously threatened, Vietnam became to increase diplomatic activities with the U.S (Quang, 2017, par. 8).

While many believed that there would be more hostility ahead of the Sino-Vietnamese relations, interaction between the two countries ultimately calmed down and peaceful diplomatic activities resumed. Right after the turning of the year in 2017, the Communist Party of Vietnam (CPV) chief, Secretary-General Nguyen Phu Trong, visited Beijing. The visit signaled that Hanoi adopted a more practical strategy towards managing its relationship with its neighbor. 


\section{Summary}

In summary, the ambitious One Belt, One Road initiative is set to change Eurasia's infrastructure, economic, and political landscapes. The unprecedentedly broad scope of OBOR has attracted attention from around the world. Because OBOR represents China's effort to achieve political objectives by economic means, it is frequently regarded as China's Marshall Plan. This research investigated the validity of such claim by comparing the two strategies' economic and political motivations. From an economic point of view, OBOR is used as a means to export China's excess capacity in traditional industries such as steel. Such motive is similar to that of the Marshall Plan, in which the U.S. was desperate to expand external markets to absorb its excess capacity at home. As a result, OBOR can be regarded as China's Marshall Plan in this context.

From the perspective of their political impacts, OBOR and the Marshall Plan share similarities as well. First, they both tried to enhance regional securities by improving regional economic conditions and political cooperation. Second, they both served to counterbalance political influences from another great power on those regions. Third, while the Marshall Plan altered Europe's political economy to be congenial to that of the U.S., OBOR secured a favorable growth environment for China by acquiring natural resources that the world's second biggest economy will need in the future. Finally, while the Marshall Plan strengthened the U.S.'s status as the world's super power, OBOR promoted China's leadership in Eurasia and will amplified the country's political voice in the region.

Although the political results of OBOR and the Marshall Plan seemed similar, the rationales behind them are fundamentally different. The Marshall Plan served to preserve the U.S.'s value, or what China often calls “ideology”. Such value includes liberalism, capitalism, and democracy. This made the Marshall Plan ideological, isolationist, and interventionist in nature. OBOR, in contrast, reveals China's comparatively short-term and practical focus on its regional interest, which includes its access to natural resources, control of trade routes, and a stable regional investment environment. As a result of such political realism and pragmatism, OBOR is ideological-neutral and consistent with the non-interventionism in China's foreign policy. To put it another way, in the Marshall Plan, the U.S. derived its interest from its ideology. In contrast, in OBOR, China hides away its value in order to more conveniently cooperate with OBOR countries to serve its interest. Although OBOR and the Marshall Plan have similar political results, the rationales behind them are fundamentally different. 
After investigating in OBOR's motivations by comparing it with the Marshall Plan, this research then examined OBOR in the context of China's evolving national strategy and foreign policy. This research argues that OBOR is an organic extension of China's national strategy since the 1990s when it began to encourage domestic enterprises to "go out" and make efforts to secure raw materials and trade routes. OBOR also inherited the principles underlying China's foreign policy since the 1950s. The non-interventionism underlying OBOR is not just political rhetoric but one of the principles that China largely adhered in the past six decades. Nevertheless, as China became increasingly involved in different countries' economies, it will become increasingly challenging for the Asian giant to abstain from political intervention in these countries. After all, noninterventionism is a product of China's political pragmatism. In the past when China was weak, it was a practical strategy to concentrate on its domestic agenda while fending off external intervention. However, as the country expanded into the world's second biggest economy, it is now practical for China to take on more regional leadership. Such striving for leadership is clearly seen in OBOR's design. While OBOR is an extension of China's existing international activities, the intentional branding of them indicates a change in China's attitude towards its international leadership. China's will to become a regional power is real. 


\section{References}

\section{Online News Articles and Magazines}

Abbate, Francesco, and Silvia Rosina. "ASEAN-China Trade Growth: Facts, Factors and Prospects." New Mandala. 26 June 2016. Web. <http://www.newmandala.org/asean-china-tradegrowth-facts-factors-and-prospects/>.

Alam, Kazim. "2015-16: China Helps as FDI in Pakistan Surges 38.8\%." The Express Tribune. 21 July 2016. Web. <http://tribune.com.pk/story/1146075/2015-16-china-helps-fdi-pakistan-surges-38$8 />$.

Bender, Jeremy, and Armin Rosen. "This Pentagon Map Shows What's Really Driving China's Military and Diplomatic Strategy." Business Insider. 13 May 2015. Web.

<http://www.businessinsider.com/this-map-shows-chinas-global-energy-ties-2015-5 >.

Chance, Alek. "The 'Belt and Road Initiative' Is Not 'China's Marshall Plan'. Why Not?" The Diplomat. 26 Jan. 2016. < http://thediplomat.com/2016/01/the-belt-and-road-initiative-is-notchinas-marshall-plan-why-not/>.

Chen, Dingding. "Defining a 'New Type of Major Power Relations'." The Diplomat. 08 Nov. 2014. Web. <http://thediplomat.com/2014/11/defining-a-new-type-of-major-power-relations/>.

Chen, Liubin. "China, Vietnam Agree to Manage Differences on South China Sea." China Daily. 14 Jan. 2017. Web. <http://usa.chinadaily.com.cn/world/2017-01/14/content_27955854.htm>.

Clover, Charles, and Michael Peel. "China tries chequebook diplomacy in Southeast Asia." Financial Times. 7 Nov. 2016. Web. <https://www.ft.com/content/abb35db2-a4cc-11e6-8b69-

02899e8bd9d1>.

Cohen, David. "China and Non-intervention." The Diplomat. 03 Dec. 2011.

<http://thediplomat.com/2011/12/china-and-non-intervention/>.

Collinson, Stephen. "Asia Trade Deal: Obama's Pivot to Nowhere." CNN. 15 June 2016.

<http://www.cnn.com/2015/06/16/politics/obama-trade-china-asia-pivot/>.

Frolovskiy, Dmitriy. "Kazakhstan's China Choice." The Diplomat. 07 July 2016. Web. 25 Apr. 2017. <http://thediplomat.com/2016/07/kazakhstans-china-choice/>.

General Office of the State Council (国务院办公厅). "Guiding Opinion on Eliminating Severe Excess Capacities (国务院关于化解产能严重过剩矛盾的指导意见)." The Central People's Government of the People's Republic of China (中华人民共和国中央人民政府). 2013. Web. <http://www.gov.cn/zwgk/2013-10/15/content_2507143.htm>.

Hong Kong Trade Development Council. The Belt and Road Initiative: Six Economic Corridors Spanning Asia, Europe and Africa. Digital image. Hong Kong Trade Development Council. 21 Jan. 2016. Web. 
$<$ http://china-trade-research.hktdc.com/business-news/article/The-Belt-and-Road-Initiative/TheBelt-and-Road-Initiative/obor/en/1/1X000000/1X0A36B7.htm>.

Indian Defense. Over 80 percent of China's crude oil imports transit the Strait of Malacca. Digital image. Indian Defense. Indiandefense.com, 21 May 2011. Web.

$<$ http://indiandefence.com/threads/naval-base-gawadar-for-china-pakistan-gives-a-greenlight.6949/page-3>.

Jamal, Nasir. "Competition for Local Steel." Dawn. 10 Oct. 2016. Web.

<https://www.dawn.com/news/1289189>.

Jennings, Ralph. "China Says Interests Outweigh Differences with Vietnam." Reuters. 13 Sept. 2016. Web. <http://www.reuters.com/article/us-china-vietnam-idUSKCN11J00X>.

Mangi, Faseeh. "China's New Silk Road Hinges on a Small Pakistan Port." Bloomberg. 29 Sept. 2016. Web. <https://www.bloomberg.com/news/articles/2016-09-29/china-s-new-silk-road-hinges-ona-small-pakistan-port $>$.

Martin, Peter. "The Humbling of the NDRC: China's National Development and Reform Commission Searches for a New Role Amid Restructuring." Jamestown. 06 Mar. 2014. Web. $<$ https://jamestown.org/program/the-humbling-of-the-ndrc-chinas-national-development-andreform-commission-searches-for-a-new-role-amid-restructuring/>.

NDRC (The National Development and Reform Commission). "Vision and Actions on Jointly Building Silk Road Economic Belt and 21st-Century Maritime Silk Road." The National Development and Reform Commission. 28 Mar. 2015. Web. 2016. <http://en.ndrc.gov.cn/newsrelease/201503/t20150330_669367.html>.

Pakistan Defense. The Gwadar Port allows China to bypass the Strait of Malacca and access Indian Ocean more easily. Digital image. Pakistan Defense.17 May 2015. Web.

$<$ http://defence.pk/threads/regarding-gwadar-port.375846/>.

Quang, Nguyen Minh. "The Resurgence of China-Vietnam Ties." The Diplomat. 25 Jan. 2017. Web. <http://thediplomat.com/2017/01/the-resurgence-of-china-vietnam-ties/>.

Shapard, Wade. "China's Jewel in the Heart of the Indian Ocean." The Diplomat. 10 May 2016. Web. <http://thediplomat.com/2016/05/chinas-jewel-in-the-heart-of-the-indian-ocean/>.

Shinn, David. "Africa Test's China's Non-interference Policy." China-US Focus. 15 May 2014. Web. $<$ http://www.chinausfocus.com/foreign-policy/africa-tests-chinas-non-interference-policy/>.

Suzuki, Wataru, and Elwida Maulia. "China Overtakes Japan in Indonesia Direct Investment." Nikkei Asian Review. 25 Jan. 2017. Web. 16 Apr. 2017. < http://asia.nikkei.com/PoliticsEconomy/International-Relations/China-overtakes-Japan-in-Indonesia-direct-investment>. 
Tiezzi, Shannon et al. "Evaluating the 'Rebalance to Asia': Interview with J. Stapleton Roy." The Diplomat. 02 Nov. 2016. Web. <http://thediplomat.com/2016/11/evaluating-the-rebalance-to-asiainterview-with-j-stapleton-roy/>.

Wines, Michael. "China Willing to Spend Big on Afghan Commerce." China Willing to Spend Big on Afghan Commerce. New York Times. 29 Dec. 2009. Web.

<http://www.nytimes.com/2009/12/30/world/asia/30mine.html>.

Zou(邹), Yunhan(蕴涵). "The Status Quo of China's Excess Capacity and Advice for Eliminating It (我国产能过剩现状及去产能政策建议)." State Information Center (国家信息中心).2016. Web. <http://www.sic.gov.cn/News/455/7349.htm>.

\section{Books, Journals, Reports, and Databases}

Brun, Lukas. Overcapacity in Steel - China's Role in a Global Problem. Rep. Duke Center on Globalization, Governance \& Competitiveness, Sept. 2016. Web. <www.cggc.duke.edu/>.

Carew, Anthony. Labour under the Marshall Plan: The Politics of Productivity and the Marketing of Management Science. Detroit: Wayne State UP, 1987. Print.

Chen, Yuan, and Yingyi Qian. The Belt and Road: A Financial Perspective (written in Chinese). Beijing: CITIC Press Group ${ }^{19}$, 2016. Print.

Downs, Erica. "Mission Mostly Accomplished: China's Energy Trade and Investment along the Silk Road Economic Belt.” China Brief XV.6 (2015): 2. 19 Mar. 2015. Web. <https://jamestown.org/wpcontent/uploads/2015/03/China_Brief_Vol_15_Issue_6_1_02.pdf>.

(The) Economist Intelligence Unit. "One Belt, One Road”: An Economic Roadmap. Rep. The Economist Intelligence Unit, 2016. Web. <http://www.eiu.com/topic/one-belt-one-road>.

Focus Economics. "Steel Price (USA) | Historical Charts, Forecasts, \& News." Focus Economics. 2017. Web. $<$ http://www.focus-economics.com/commodities/base-metals/steel-usa>.

Gallagher et al. Fueling Growth and Financing Risk: The Benefits and Risks of China's Development Finance in the Global Energy Sector. Rep. Boston: Boston University, 2016. Web.

<https://www.bu.edu/pardeeschool/files/2016/05/Fueling-Growth.FINAL_.version.pdf >.

Hogan, Michael J. The Marshall Plan: America, Britain, and the Reconstruction of Western Europe. Cambridge: Cambridge University Press, 1987. Print.

\footnotetext{
${ }^{19}$ CITIC Press Group (referred to as CITIC Publishing Group in The Belt and Road: A Financial Perspective) is a leading publishing and knowledge service group in China, with yearly publishing business scale over $¥ 1$ billion (\$147 million) according to its official website. < http://press.citic/html/singlepage1.html>
} 
International Trade Administration. Global Steel Monitor - Steel Exports Report: China. Rep.

International Trade Administration, Dec. 2016. Web.

$<$ http://trade.gov/steel/countries/pdfs/exports-china.pdf $>$.

Lampton, David M. Following the Leader: Ruling China, from Deng Xiaoping to Xi Jinping. Berkeley: University of California, 2014. Print.

Leer, Yeroen van der, and Joshua Yau. China's New Silk Route: The Long and Winding Road. Rep. PricewaterhouseCoopers, 2016. Web. <https://www.pwc.com/gx/en/growth-marketscenter/assets/pdf/china-new-silk-route.pdf $>$.

Reynolds, David. "The European Response: Primacy of Politics." Foreign Affairs 76.3 (1997): 171-84. JSTOR. Web. 18 Jan. 2016. <http://www.jstor.org/stable/20048106>.

Salidjanova, Nargiza, Iacob Koch-Weser, and Jason Klanderman. China's Economic Ties with ASEAN: A Country-by-Country Analysis. Rep. U.S.-China Economic and Security Review Commission, 17 Mar. 2015. Web.

<https://www.uscc.gov/sites/default/files/Research/China's $\% 20$ Economic $\% 20$ Ties $\% 20 w i t h \% 20$ ASEAN.pdf>.

Scissors, Derek. "China Global Investment Tracker." China Global Investment Tracker. The American Enterprise Institute, 2017. Web. < https://www.aei.org/china-global-investment-tracker/>.

Statista. "China: Export of Goods 2015 | Statistic." Statista. 2016. Web.

<https://www.statista.com/statistics/263661/export-of-goods-from-china/>.

Storey, Ian. "China’s "Malacca Dilemma". China Brief VI.8 (2016). 12 Apr. 2006. Web.

$<$ https://jamestown.org/program/chinas-malacca-dilemma/>.

Swaine, Michael D. Chinese Views and Commentary on the "One Belt, One Road" Initiative. Rep. no. 47. China Leadership Monitor, 2015. Web.

<http://www.hoover.org/sites/default/files/research/docs/clm47ms.pdf>.

(The) World Steel Association. Steel Statistical Yearbook 2016. Rep. Brussle: World Steel Association, 2016. Web. <https://www.worldsteel.org/en/dam/jcr:37ad1117-fefc-4df3-b84f-

6295478ae460/Steel+Statistical+Yearbook+2016.pdf $>$. 
